\title{
IDENTIDADE E SEXUALIDADE NO DISCURSO ADOLESCENTE*
}

\section{IDENTITY AND SEXUALITY IN ADOLESCENT DISCOURSE}

\author{
Carla Magda Allan Santos Domingues ${ }^{1}$ \\ Augusta Thereza de Alvarenga ${ }^{2}$
}

DOMINGUES, C. M. A. S.; ALVARENGA, A. T. Identidade e Sexualidade no Discurso Adolescente. Rev. Bras. Cresc. Desenv. Hum., São Paulo,7(2), 1997.

\begin{abstract}
Resumo: Tendo em vista interpretar a concepção de adolescência a partir do discurso dos próprios sujeitos sociais, o presente trabalho objetivou caracterizar o processo de construção da identidade do adolescente, a partir de múltiplas identificações que o conformam. Considerando que na adolescência relações de género emergentes e manifestações da sexualidade assumem significações particulares no processo de formação dessa identidade procurou-se, igualmente, reter tais aspectos com a finalidade de apreender as características assumidas no processo considerando o espaço social tia qual se movimentam. Nesse sentido, a identificação de padrões culturais, valores sociais e ideológicos, que formam e conformam tal processo, passam a representar o universo no qual se inscreve o grupo estudado, caracterizado por 31 adolescentes estudantes, entre 15 a 19 anos, de ambos os sexos, categorizados em três segmentos sociais, pertencentes a dada área do Município de São Paulo.
\end{abstract}

Palavras-chave: adolescente, identidade, sexualidade, género, pesquisa qualitativa, análise de discurso.

\section{INTRODUÇÃO}

A adolescência tem se constituído, na atualidade, em importante objeto de preocupação para várias disciplinas científicas, tendo em vista a grande expressão que passa a assumir no interior das transformações de diferentes ordens que caracterizam o mundo contemporâneo.

Entendida como um fenômeno das sociedades modernas, o surgimento da adolescência dáse no final do século XIX e início do século XX, com o incremento da urbanização e industrialização. Para JOSEPH (1993), as mudanças econômicas e sociais deste período tiveram efeitos es- pecialmente sobre os grupos de idade. Até a metade do século XIX, a idade não constituía um fato importante ou mesmo revelador da experiência sócio-histórica. Assim, emerge entre a infância e a idade adulta como um período intermediário por configurar características próprias que a diferenciam dos demais períodos. Por não serem mais criança e, ao mesmo tempo, ainda não terem se tornado adulto, com dada idade cronológica, os indivíduos de uma dada faixa etária começam a viver uma fase considerada de transição.

A transição para o mundo adulto torna-se cada vez mais complexa uma vez que, do ponto de vista histórico, há um longo período de preparação

\footnotetext{
* Este trabalho consiste em uma versão resumida da Dissertação de Mestrado apresentada à Faculdade de Saúde Pública da USP1997.

1 Técnica do Centro Nacional de Epidemiologia da Fundação Nacional Saúde/MS.

2 Profa. Dra. do Departamento de Saúde Materno-Infantil da Faculdade de Saúde Pública/USP. End.: Av. Dr. Arnaldo, 715, 2 andar Sala 218 - São Paulo-SP - CEP: 01246-904 - Tel.: 3066-7702 e 7703.
} 
que agudiza a descontinuidade entre o mundo das crianças e o do adulto que, se comparado ao das sociedades primitivas; é menos institucionalizado e com papéis menos definidos, além de haver uma maior segmentação dos espaços de elaboração das identidades, constitutivas da "transição" de uma sócio-psicológica para outra.

Esta preparação é confiada basicamente a instituições como a escola, cuja função é a transmissão de conhecimentos e valores para o desempenho da vida futura, inclusive profissional. Sendo voltada para um momento posterior implica numa enorme segregação do mundo adulto e um longo adiamento da maturidade social, desconectanda da maturidade sexual e fisiológica.

O período de "espera", constituído idealmente pelos anos escolares, faz com que os papéis aí desempenhados não correspondam às necessidades, de diferentes ordens, surgidas no processo de formação do adolescente. Daí a tendência do mesmo a constituir grupos espontâneos de pares, nos quais possa elaborar tais respostas. À medida em que esses grupos passam a representar um foco potencial de comportamento fora da normalidade ou de propostas de transformação social traz à tona o caráter problemático da constituição dos grupos juvenis, pois vai atuar de forma decisiva na transmissão da herança sóciocultural, passada de geração a geração. E a partir daí que a juventude vai se constituir numa categoria social nas sociedades ocidentais, modernas e industriais, transformando-se num problema das sociedades contemporâneas.

É principalmente no século XX, que há uma ampliação da condição juvenil, passando a ser englobada por outros setores sociais e se diversificando, transformando seus significados e formas de aparição, seus referênciais e limites etários.

A juventude, então, vai despertar interesse como tema de estudo à medida em que determinados grupos juvenis parecem problematizar o processo de transmissão das normas sociais, ou seja, quando se tornam visíveis o aparecimento de jovens com comportamento que fogem aos padrões de socialização aos quais deveriam, em termos funcionais, estar submetidos. Dentre outros autores, Ariès, citado por ABRAMO (1994), afirma que essa visibilidade é percebida através dos grupos de jovens delinqüentes, excêntricos ou contestadores, de forma que, embora diferentes, todos contrastam com os padrões vigentes.

Assim, apesar da ampla gama de definições existentes sobre a questão da juventude, independente do referencial teórico adotado, algumas noções podem, segundo ABRAMO (1994), ser identificadas como a questão da transitorieda- de - etapa de transição, período de preparação para o ingresso na vida adulta, porém, sem a existência de limites precisos entre o inicio e o término, nem demarcação através de rituais socialmente reconhecidos, com direitos e deveres não explicitamente definidos nem institucionalizados - o que imprime à condição juvenil uma imensa ambigüidade.

Com o processo de modernização das sociedades a juventude, como período marcadamente social, passa a se caracterizar como segundo processo de socialização, depois da infância, consistindo, fundamentalmente, na preparação dos jovens para a assunção dos papéis modernos relativos à profissão, casamento, cidadania política, entre outros, objetivando prepará-los para enfrentar uma série de escolhas e decisões. Nesse sentido é que a partir dos anos 40 amplia-se o enfoque sobre os estudos da juventude, tendo em vista englobar as questões relativas a comportamentos específicas de grupos de adolescentes, considerados como "normais" e centrados, basicamente, nos escolares.

Tal processo representa a gênese do que na atualidade, se conhece como comportamento jovem, ou seja, a identificação com os grupos de pares que os diferencia do mundo infantil do mundo adulto pelo desenvolvimento de rituais, simbolos, modas e linguagens peculiares, que se apresentam como marcadores de uma busca de identidade própria.

Essa subcultura juvenil ganha amplo espaço social não se reduzindo, portanto, ao sistema educacional. De acordo com Parsons, citado por ABRAMO (1994), essa subcultura constituída a partir da cultura geral dos adultos com a finalidade central de promover a transição social entre a infância e a idade adulta. Passa a ter, portanto, na visão Parsoniana, a função de "transição geracional”, além de garantir a continuidade social e a abertura para a modernização. Neste sentido é que, nessa abordagem, subcultura juvenil é contraposta a cultura geral dos adultos, sem necessariamente ser hostil ou antagônica a ela.

Esta ampliação da concepção de juventude, re-significa o conceito de juventude delinqüente, uma vez que encarados como grupos minoritários, e nao são mais vistos como consequência de disfunções do processo de modernização esta categoria de adolescentes não pode ser tomada, portanto, como expressão de juventude “normal”. No entanto, vale lembrar que o cerne desta concepção de juventude sempre conterá, a despeito dos diferentes “olhares”, a possibilidade da existência de ruptura potencial de radicalidade, a partir de determinados grupos de jovens capazes de alavancar processos de transformação social. 
Neste contexto histórico os adolescentes são percebidos como sujeitos sem identidade própria porque sua vivência e projeção para o futuro constituem-se em elementos para o estabelecimento da identidade adulta. Ao mesma tempo são descaracterizados como crianças.

Vivenciar experiências com seu grupo de pares talvez seria a principal aspiração de todo adolescente, pois só desta maneira perderá “definitivamente" sua condição de criança e, ao mesmo tempo, poderá participar do mundo adulto. sem no entanto, ser ou tornar-se precocemente um adulto. Na procura deste novo status passa a estabelecer novas relações familiares e sociais, no interior das quais defronta-se com a necessidade de incorporar novos valores sociais, criar e recriar uma concepção acerca de si mesmo a partir de experiências próprias, mas, sobretudo, das expectativas e exigências sobre seu comportamento social. Tais pautas apontam não para o presente, mas para o devir, por implicar assunção de novos papéis sociais, a necessidade de uma escolha profissional e possibilidades de ascensão social, sua própria definição pessoal assim como seu papel sexual. São processos constitutivos da construção de sua identidade adolescente, sinalizadores emergentes de relações sociais e afetivo-sexuais inscritas neste novo momento de sua existência.

Os importantes questionamentos que surgem na adolescência dos tipos, "Quem sou eu? O que eu posso? O que eu quero? Como o outro me vê ou me aceita? Para onde vou?”, representam a busca do jovem do conhecer a si mesmo através da diferenciação do que foi e do que gostaria de ser. Muito além de ser uma fase de preparação para a entrada no mundo adulto e um momento de reconhecer-se enquanto sujeito de sua própria história capaz, portanto, de transformar-se em sujeito, constituindo-se como tal não como um mero ser em transição. SANCHES (1994) ressalta que é através da convivência com o grupo de amigos, "os iguais", que os adolescentes permanecem no idêntico e defendem-se contra a diferença, pois é através do grupo que o adolescente encontra possibilidades de se reconhecer, através do outro, como espelho, diferenciando-se, então, daquilo que não quer ser, a criança, e daquilo que ainda não é, o adulto.

As mudanças históricas e culturais terão papel fundamental neste processo de formação da identidade, pois abrem as possibilidades de rompimento da coerência interna das expectativas da criança. Para CIAMPA (1984), a identidade do indivíduo implica diferenças e igualdades que sucessivamente se apresentam, de acordo com os vários grupos sociais dos quais fazemos parte. Assim, o conhecimento que nós temos de nós mesmos é obtido pelo reconhecimento recíproco dos indivíduos identificados em um determinado grupo social, que existe objetivamente. Esta identificação se dá através das relações que os membros estabelecem entre si e com o meio onde vivem, pela sua prática e ação.

No mesmo sentido, CIAMPA (1987) afirma que as identidades dos indivíduos repetem a estrutura social, pois, ao mesmo tempo reagem sobre ela conservando-a ou transformando-a. Daí, não poder haver, portanto, uma dissociação do estudo da identidade do indivíduo com o da sociedade, na medida em que as várias configurações de identidade estão relacionadas com as diferentes configurações da ordem social.

Entender o processo de construção da identidade a partir desta Ética significa considerá-la como um objeto em constante transformação, à medida em que assumimos vários papéis ao longo de nossa história. Neste sentido, a adolescência não poderia ser considerada uma fase apenas de transição, na qual são criadas condições para o estabelecimento da identidade adulta. Tendo em vista que nesta fase vivências e papéis sociais assumidos são inerentes a esta, nosso pressuposto é a possibilidade de que exista uma identidade própria de grupo.

Assim considerado, é a partir deste caráter dinâmico da identidade, que o processo de estruturação e reestruturação da identidade dos jovens poderia ser observado, num contexto sócio-cultural de mudanças aceleradas, com impacto decisivo na vida dos adolescentes. Este processo de construção da identidade adolescente, que é entendida não como única, mas como a configuração de múltiplas identidades, surgirá à medida em que se estabeleçam identificações decorrentes das várias vivências que sua condição de existência passa a possibilitar.

Sendo na adolescência que ocorre as maiores possibilidades de identificações de gênero e de sexo, consideramos que o exercício da sexualidade apresenta-se como elemento importante na formação da identidade adolescente, manifestada através de múltiplas identificações características, como a da imagem corporal, a da identificação com o masculino e/ou feminino, a da descoberta do "outro" como objeto de amor ou desejo, dentre outras.

Inscrita em diferentes contextos históricos, a análise do "ser adolescente" ganha especificidades à medida em que a construção social da identidade do adolescente e a questão da sexualidade a ela atrelada movimentam-se numa rede de relações macro e micro sociais, no interior da qual emergentes relações de gênero são passíveis de serem apreendidas e caracterizadas. 


\section{PROCEDIMENTO METODOLÓGICO}

\section{Modalidade da Pesquisa e Seleção dos Sujeitos Sociais}

Para a abordagem do tema em estudo, realizamos uma pesquisa qualitativa, buscando identificar o universo de dado grupo de adolescentes, a partir da análise de depoimentos proferidos por sujeitos sociais inscritos na faixa etária de 15 a 19 anos, estudantes pertencentes a diferentes segmentos sociais.

O material empírico foi coletado através da técnica de entrevista, baseado em um roteiro temático, tendo seu conteúdo definido em função de aspectos que consideramos relevante reter do objeto com base na literatura existente, mas também em função do resultado de quatro entrevistas exploratórias realizadas previamente.

Como estratégia de aproximação ao conceito de "classe social", utilizamos a metodologia empregada no estudo "Sexualidade e Plano de Vida na Adolescência”, desenvolvido em 1993, no Estado de São Paulo, pela Secretaria de Estado da Saúde, através do Grupo de Atenção à Saúde do Adolescente, sob a promoção da Organização Mundial da Saúde - OMS ${ }^{3}$.

Tal metodologia consistiu na identificação de "segmentos sociais", com base nas seguintes categorias: padrão;

A - significa estudantes de escola de alto

B - significa estudantes de escola de bairros típicos de classe média;

C - significa estudantes de escola de bairros periféricos e/ou trabalhadores;

D - significa moradores de bairros periféricos que não estavam estudando no momento da entrevista, independente de estarem ou não trabalhando.

Uma vez que, pela sua natureza, a proposta da pesquisa não buscou quantificar nem realizar testes de significancia estatística, mas qualificar e contextualizar o discurso dos adolescentes, optamos por fazer uma adaptação da metodologia empregada pelo estudo da Secretaria de Estado da Saúde, selecionando jovens em três destas categorias, como abaixo descriminado:

A: Estudantes de Escolas de Alto Padrão

Enquadram-se nessa categoria jovens que estavam matriculados no momento da entrevista, ou em escolas particulares com mensalidade superior a 2 salários mínimos, ou em cursos univer- sitários (públicos ou particulares) de dedicação integral, ou em cursos universitários de meio período, podendo estar trabalhando se não exercessem atividade remunerada, ou seja, atividades que configurassem estágio profissional. Portanto, os jovens dessa categoria deveriam ser os que possuíam tempo integral para investir em sua educação, em condições privilegiadas.

B: Estudantes de Escolas de Bairros Típicos de Classe Média.

Enquadram-se nessa categoria adolescentes que estavam matriculados no momento da entrevista em escolas públicas nesse tipo de bairro. Quando exerciam tarefa remunerada em ocupação alheia ao seu programa de estudo, não poderiam despender para tanto, mais de meio período. Ou seja, os jovens dessa categoria deveriam dispor de pelo menos meio período do dia para investirem em seu futuro educacional. Os que dispusessem de período integral para tanto, seriam considerados diferenciados dos jovens da categoria anterior, por possuírem uma renda familiar mais baixa expressa, indiretamente, pelo valor da mensalidade escolar e pela localização da escola.

C: Estudantes de Escolas de Bairros Periféricos e/ou Trabalhadores.

Enquadraram-se nessa categoria adolescentes que necessitavam trabalhar para ajudar na composição da renda familiar. Poderiam, eventualmente, estar desempregados no momento da entrevista. Se estivessem estudando no momento da entrevista, deveriam cursar escolas públicas, de bairros periféricos. Caso contrário, deveriam ter obrigatoriamente abandonado os estudos por conta de dificuldades financeiras. Ou seja, enquadram-se nessa categoria, os jovens com horizonte educacional limitado pela condição financeira. Em geral, não dispunham da metade do dia para se dedicar aos estudos, precisando estudar à noite. Aqui, a renda seria medida, indiretamente, pelo local de moradia e, em caso de estarem estudando, por ser em escola pública de bairros periféricos.

Portanto, os sujeitos sociais que se constituíram como objeto de estudo foram selecionados levando-se em conta sua inserção em "segmentos sociais" de A a C, com idades de 15 a 19 anos, sendo 16 do sexo feminino e 15 do sexo masculino, o que constitui um universo de 31 entrevistados.

Como estratégia para melhor visualização dos discursos dos adolescentes, em função da sua localização no "segmento social", os nomes verdadeiros foram substituidos por outros, iniciados

3 A referida investigação, sob a coordenação de Albertina Duarte Takiuti, Coordenadora do Grupo de Atenção à Saúde de Adolescente, encontra-se em fase de tratamento e análise dos dados. 
com as letras A, B e C, cujas iniciais correspondem aos respectivos segmentos sociais A, B e C, conforme o abaixo especificado:

- nomes masculinos e femininos iniciados pela letra A correspondem aos adolescentes do "segmento social” A;

- nomes masculinos e femininos iniciados pela letra B correspondem aos adolescentes do "segmento de social” B;

- nomes masculinos e femininos iniciados pela letra C correspondem aos adolescentes do "segmento social” C.

O registro dos proferimentos foi feito através de gravação com a transcrição realizada por entrevistadores, tendo em vista recuperar de maneira mais segura o ambiente e a forma de como ocorreu a entrevista. Nesse particular, as hesitações, as pausas, os risos e outras manifestações similares foram transcritas e consideradas de grande relevância para o processo de interpretação.

\section{ANÁLISE DOS DADOS}

Optamos pela utilização da técnica de análise de conteúdo para o tratamento e interpretação dos dados da pesquisa.

Segundo BARDIN (1977), a análise de conteúdo pode ser definida como "um conjunto de técnicas de análise de comunicação visando obter, por procedimentos sistemáticos e objetivos de descrição do conteúdo das mensagens, indicadores (quantitativos, ou não) que permitam a inferência de conhecimentos relativos às condições de produção/ recepção das mensagens” (p. 42).

Para MINAYO (1996), o elemento comum desse conjunto de técnicas está baseado na inferência que, podendo ultrapassar o conteúdo manifesto da mensagem, atinge, mediante esta, uma interpretação mais profunda. E através da inferência, portanto, que se confere a essas técnicas relevância teórica, uma vez que implica, pelo menos, uma comparação onde a informação puramente descritiva sobre o conceito é de pequeno valor.

Um dado sobre conteúdo de comunicação é sem sentido até que relacionado, no mínimo, com outro dado. Isto porque, o vínculo existente entre dados é passível de ser representado, segundo FRANCO (1986), por alguma forma de teoria que permite interpretar e dar sentido às falas dos sujeitos sociais.

Desta forma, para FRANCO (1986, p. 16), “produzir inferências, em análise de conteúdo, tem um significado bastante implícito e pressupõe a comparação de dados obtidos na leitura do discurso, com pressupostos teóricos de diferentes concepções de mundo e com situação concreta de seus produtores e receptores. Situação concreta que se expressa nas condições de sobrevivência e na situação de classe de ambos os elementos, acrescida do momento histórico e contextual da produção e/ou recepção”.

Segundo BARDIN (1977), o aspecto referencial da análise de conteúdo que fundamente a sua unidade e especificidade pode responder a dois tipos de problemas, ou seja: $1^{\circ}$ ) o que é que conduziu a um determinado enunciado - este aspecto diz respeito às causas antecedentes da mensagem - e $2^{\circ}$ ) quais as conseqüências das mensagens - os efeitos de comunicação.

Nesta pesquisa, trabalhamos com a indagação sobre causas antecedentes da mensagem, pois partimos de indagações acerca de "quem" e do "por que" de determinado conteúdo a ser trabalhado, do ponto de vista do produtor, ou melhor, do sujeito social entrevistado.

Como estratégia metodológica, teórico-técnica, optamos por realizar uma análise temática do universo do adolescente, conforme conceito de BERELSON (1971), que se baseia na definição de categorias elaboradas a partir do discurso dos adolescentes, consideradas como uma afirmação acerca do tema sob investigação, ou seja, uma frase simples ou composta; habitualmente um resumo de uma frase condensada, pode estar interligada a um vasto conjunto de informações singulares. Neste sentido, a estratégia fundamental constituiu-se em definir núcleos de sentido que compõem o processo de comunicação entrevistador-entrevistado e cuja presença ou seqüência de aparição possam dar significado para o processo de desvelamento dos discursos dos adolescentes como sujeitos sociais.

\section{ANÁLISE DOS DISCURSOS}

A fim de interpretar as falas dos adolescentes entrevistados, procuramos identificar elementos estruturadores dos discursos proferidos que pudessem ser decompostos em categorias e sub-categorias conformando, desta forma, o eixo de análise dos mesmos.

Com esta estruturação pretendemos buscar os contornos do sistema de significação que, no seu conjunto, revelassem as representações construídas, em nível dos discursos, pelo grupo de adolescentes estudantes, de diferentes segmentos sociais, constitutivos do modo de como entendem a adolescência, a existência de identidade própria e a sexualidade em múltiplas manifestações.

Partimos da sistematização de três categorias que representam o eixo temático em torno do qual os depoimentos se articulam, a saber: 

lescência.

\section{1 - Percepção e concepção da própria ado-}

2 - Identidade de gênero na adolescência.

3 - Re-construção dos valores sexuais e seu papel na identidade de gênero.

\section{Percepção e Concepção da Própria Adolescência}

A concepção do adolescente acerca de sua condição de existência, e como o mesmo se percebe enquanto tal, não apresentou, em nível do discurso dos sujeitos investigados, grandes variações quer por sexo, ou "segmento social”, o que parece apontar para a existência e uma homologia do "ser adolescente", independentemente das condições sociais em que estejam inseridos. Algumas categorias específicas aparecem como relevantes neste processo de entendimento do auto-conceito. É revelador o fato de o parâmetro definidor da adolescência como condição de existência com identidade própria apresentar-se no forte sentimento de pertencimento a dado grupo de “pares”, cujas características são definidas ora por negação ao ser criança e ser adulto, ora (e sobretudo) pela afirmação do ser adolescente como entidade e individualidade distinta.

Como eixo promotor desse processo de individualização na adolescência destaca-se, principalmente, a busca de autonomia associada, por um lado, à percepção da existência e assunção de responsabilidades próprias que, embora ligadas a dado projeto de futuro, ainda o diferencia do "já ser” adulto e do "ainda ser” criança, conferindolhe especificidades. Por outro lado, está presente a concepção do "ser” livre, diferente, que busca desligar-se do grupo familiar e identificar-se com o grupo de pares, no interior do qual partilha um sistema de valores próprios, quase sempre de negação, em nível de aparência, de valores societários vigentes.

\section{Busca da autonomia}

Na literatura especializada a adolescência é considerada, de maneira característica, como um momento da vida do indivíduo no qual os conflitos intergeracionais aparecem de maneira manifesta e típica com relação a família, escola, demais grupos sociais ou institucionais do qual o adolescente faz parte. Apresenta-se como uma forma característica de negação dos valores e normas sociais instituídas, que possam cercear a afirmação da sua busca de autonomia relacionada a descoberta e definição de seu lugar no mundo.

Nesse processo, o significado de tal busca é, por vezes, indefinida, vaga, encoberta, muito embora o adolescente a reconheça como uma situação de conflito.
"Você quer agredir, quer mostrar que já cresceu, tem as brigas, com os meus amigos eu me dou bem, gosto de conversar, conheço bastante gente, mas com meus pais é muito tumultuado, tem briga mas é sem ressentimento porque eu gosto de agitar, é natural" (Camila / 16 anos).

$\mathrm{O}$ conflito estabelece-se à medida em que as sociedades em geral, organizadas a partir de dadas relações sociais configuradoras de padrões culturais gerais e específicos que prescrevem formas “desejáveis” de comportamento social que vão desde a infância até a idade adulta. Define, portanto, comportamentos inerentes a cada idade, de acordo com as funções sociais préestabelecidas. Nas modernas sociedades complexas, a definição de tais pautas comportamentais torna-se cada vez mais dificil, uma vez que as formas de participação do indivíduo na vida social amplia-se, fazendo da adolescência um período onde tal processo se intensifica.

A manifestação e a intensificação das relações contraditórias presentes no mundo moderno desse "novo ser" que ora é inscrito no mundo adulto, ora é excluído, encontra explicação na grande aceleração das mudanças econômico-sociais por que passam as sociedades atuais, cujo impacto na esfera dos valores, embora presente, sofre um processo de diacronia, uma vez que formas de resistência à transformação residem sobretudo na esfera cultural e ideológica. Neste sentido, resta ao adolescente "lutar" pelo reconhecimento de sua existência no mundo moderno, numa contra-posição a resquícios de valores das sociedades tradicionais onde o mundo reconhecido era sobretudo e, muitas vezes, tão somente o dos adultos.

Considerando que a instituição familiar apresenta-se como representante mais direto da sociedade para a garantia de manutenção de valores e normas vigentes e ideologicamente sancionados, será em nível de tais relações primárias que o "confronto" do mundo adolescente e mundo adulto pode melhor ser observado.

O rompimento com o espaço da casa e, portanto, com as relações "exclusivamente familiares”, abre ao adolescente não somente as possibilidades de uma gradual emancipação dos pais mas, sobretudo, o espaço da rua (DA MATTA, 1986) permitindo o convívio e uma gama variada de múltiplas identificações com o grupo de pares (ou outros adolescentes) e a realidade social mais ampla. lescente?)

(Quando você percebeu que já era um ado-

"E quando você sente necessidade assim, que você tem sempre que tá se colocando enquanto individuo, diferente dos outros assim. Por exemplo... eu sempre... tem um pouco disso, mas tem 
um momento que você se sente que é muito forte, assim, você quer se você e nao que ser mais ninguém.

(Se sobressair?)

Não é só sobressair, mas se diferenciar... nem tanto se sobressair, não é ser o melhor, mas ser você, ser diferente.

(Em relação a quem?)

Principalmente com os pais” (Aurélio/ 19 anos).

É no interior do grupo de pares que relações de amizade e de namoro se estruturam gerando trocas, confidências e descobertas, apresentando-se como base fundamental para a construção da identidade do adolescente, passível de ser socialmente reconhecida.

Em termos psicossociais trata-se da descoberta do outro (e do mundo) como forma de identificação do não ser mais criança e não ser ainda adulto, mas ser adolescente, e enquanto tal, possuir necessidades e desejos próprios que, por um lado, o diferenciam dos demais grupos e, por outro, imprime-lhe características e existência particular, individualizado e, portanto, autônoma em relação aos exclusivos vínculos familiares.

Neste processo de ruptura da estreita ligação com os laços familiares é característico intenso convívio com o grupo de amigos, a necessidade constante de estar em grupo e a própria idealização da auto-imagem a partir da imagem do grupo, ao mesmo tempo em que o processo de construção da identidade se estabelece pela forte identificação com este.

Uma das peculiaridades marcantes de identificação do adolescente com sua condição é a adesão a determinados modos de agir e vestir do grupo de pares, como forma encontrada de tornar-se igual à turma e ser reconhecido como tal. É o culto a moda, onde a “indumentária de grifes” e os ornamentos ganham expressão de identidade grupal, independentemente da condição social e de sexo.

Mesmo para os adolescentes das classes populares, que não possuem recursos financeiros para adquirir marcas famosas de jeans ou tênis, a busca de imitação destes produtos apresenta-se como a forma de assemelhar-se aos demais. $\mathrm{O}$ modo de vestir constitui-se, assim, na maneira encontrada de excluir os diferentes e identificar os iguais; são as marcas ou sinais identificadores de ser do grupo, ou do não ser.

Trabalhar passa a ser, então, um dos elementos possibilitadores dessa pertinência, embora com significado diferenciado para as categorias sociais. Apesar de ser considerado, pela sociedade, como fazendo parte da população economicamente ativa, o grupo adolescente vê sua inserção no mundo do trabalho com diferentes olhares.

"Eu trabalho pra mim poder ter o meu próprio dinheiro, pra mim poder ter as minhas coisas, condições prá poder comprar minhas próprias coisas, minhas roupas... porque senão os meus pais não teriam condições de me darem o que eu quero, as coisas de agora... como os jovens se vestem, do jeito... como o pessoal se veste hoje em dia ... Eu procuro gastar o meu dinheiro, comprando coisas prá mim, ajudando um pouco em casa, quando a minha mãe ou o meu pai pede ... o resto eu vou colocando na poupança, quando eu tiver um bom dinheirinho pra poder comprar um carrinho mais pra frente" ( César/ 18 anos).

No caso de adolescentes pertencentes ao segmento social C, não observamos verem no trabalho uma forma de interrupção da adolescência ou mesmo de um amadurecimento precoce, mas sim a possibilidade de, com o dinheiro ganho, poder adquirir os mesmos bens que os adolescentes das classes mais abastadas, que não necessitam trabalhar, têm acesso. Neste contexto, portanto, onde os sujeitos sociais são adolescentes estudantes de diferentes segmentos sociais, o trabalho é visto como a possibilidade de viver o mesmo processo dos demais adolescentes e não se apresenta como forma de negação da sua condição.

Por outro lado, é interessante notar que apesar dos adolescentes do segmento social A também acharem que trabalhar nesta fase da vida dá aos demais adolescentes a possibilidade deles terem acesso a bens sirnilares aos seus, o significado atribuído ao trabalho dentro do seu segmento social é, no entanto, outro, na medida em que o mesmo é percebido como facilitador para que os mesmos consigam sua emancipação dos pais, ou tenham maior autonomia. Isso por não necessitarem pedir dinheiro para todas as suas despesas, sobretudo para as relativas ao lazer, que parece consistir, para essa categoria, no principal objetivo de seus gastos particulares.

"Meu pai não me deixa trabalhar, eu não preciso, mas ele não deixa.

(Voce não precisa em que sentido?)

No financeiro.

(Mas você gostaria de trabalhar.)

Até que gostaria, mas eu prefiro estudar por enquanto, mas eu não gosto em parte de depender da minha mãe, do meu pai, eu tenho que obedecer eles, eu não posso fazer uma coisa sem pedir permissão deles, então eu acho mal isso, eu posso amanhã precisar de dinheiro para o lazer, Era sair com meu amigos, mas eu dependo deles" (Ana/ 16 anos). 


\section{A incessante busca do prazer; a descoberta do novo}

Ter tempo para se divertir, aproveitar a vida, sair à noite, ir à festas, "namorar ou ficar" são atividades reitoradas nos discursos como pertencendo exclusivamente ao período da adolescência, aparecendo como característica personalizada, marcante desta fase. O “aproveitar a vida”, identificado como sendo diretamente oposto ao "levar a vida a sério", parece diferenciar o universo do adolescente do universo do mundo adulto. Revela-se na grande necessidade expressada de assegurar um momento de prazer com amigos, por considerar que o final da adolescência leva a uma vida cheia de responsabilidades, "sem tempo" para o lazer e para a diversão. "Curtir a vida”, aparece assim, como uma das principais identificações da identidade adolescente, caracterizada por um certo estilo de vida peculiar representado pelo grupo aqui estudado, independentemente dos segmentos sociais e de sexo.

"[Adolescência] é aquele periodo de curtir a vida ... em geral você tenta curtir a vida de maneira bem descontraída, não se preocupa com nada e quando está namorando escondido é meIhor ainda, a gente vive sob tensão, a adrenalina lá em cima” (Adilson/16 anos).

O sentido assumido pelo "curtir a vida", como característica peculiar desse momento da vida, adquire significado especial, no caso da adolescente, por representar a abertura, para a mulher, do espaço público da rua, antes vedado e exclusivo dos homens.

Como decorrência, passa a usufruir do mesmo, constituindo-se a diversão em parte integrante do seu cotidiano com significação para a conformação das relações de gênero.

Viver situações de perigo não só representam um grande desafio para o adolescente, mas personaliza sua condição porque através delas identifica tanto a possibilidade de descobrir o novo, como a de testar os seus próprios limites, desafiar-se, superar-se diante dó si próprio, assim como do grupo de pares.

"Olha eu acho que ele [o adolescente] gosta de descobrir as coisas e assim, as coi sas perigosas geralmente... geralmente são um mistério entendeu, o perigo é uma coisa desconhecida até que você passe por ele.

(Que coisas, por exemplo?)

Ah!, coisas assim até certo ponto irresponsáveis, por exemplo, uma coisa normal que é lidar com o carro, o adolescente quer correr, quero correr mesmo, eu corri muito e tal, aquelas loucuras ... aí o neguinho vai lá e enche a cara, pega o carro e vai no pau porque se sente o tal, sabe esse tipo de irresponsabilidade, porque a pessoa não mede a cagada que tá fazendo, isso é uma forma de desafiar o perigo, de desafiar até a sua própria condição e isso atrai o adolescente" (Ademar/ 19 anos).

Se, em um primeiro momento, as manifestações dos jovens estruturaram-se como crítica ao modo de vida industrial-burguês, dos padrões dominantes ou pela luta política contra a repressão e pela liberdade de expressão, visualizadas a partir dos modos de vida excêntricos ou contestadores (movimento juvenil alemão, hippies ou estudantis), atualmente, as manifestações juvenis não sinalizam mais para o questionamento da ordem social, porém, podem ser consideradas, como aponta Lapassade e Matza, interpretados por ABRAMO (1994), como fazendo parte do mesmo fenômeno. Ou seja, um mesmo sentimento de incômodo com o modo de vida estruturado, podendo estar sendo também entendido dentro do mesmo processo de "revolta juvenil”, que constitui a ameaça à estabilidade da ordem social. Esses novos tipos de comportamento - viver situações limites e perigosas podem ser vistos como as novas possibilidades de experimentação das sociedades modernas, porém, sob o mesmo prisma.

\section{Descoberta da responsabilidade}

A forma mais característica de reconhecimento da adolescência como despertar "consciente" do sentido da existência humana como devir histórico-social, no caso desse grupo de adolescentes não excluídos socialmente, porque participando do sistema educacional, independentemente do segmento social a que pertencem, parece revelar-se nas formas típicas de identificação com a noção de responsabilidade. Pelo discurso adolescente, trata-se de uma fase ora desprovida de tarefas específicas, portanto sem responsabilidades definidas, ora com atribuições delimitadas e restritas, características desta fase, centrada basicamente no estudo.

A adolescência é considerada uma fase sem ou com menor responsabilidade frente a responsabilidade adulta em relação ao trabalho e a família, ao mesmo tempo com uma maior liberdade, se comparada a autonomia da criança porque é caracteristicamente uma fase de descobertas do presente e do devir, identificado como mundo adulto.

"Adolescência é uma fase que você está começando a ter responsabilidade, não tem tanta coisa que te prenda, grande parte dos adolescentes não tem responsabilidade com o trabalho, não tem marido, não tem filho, não tem aquela preocupação, tem uma vida mais leve, se você souber seguir com responsabilidade, voce pode curtir muito bem esta fase” (Cláudia/16 anos). 
É neste sentido que os adolescentes pesquisados diferenciam-se dos demais grupos, infantil e adulto, pois, apesar de sinalizarem sua aspiração no sentido de participar ativamente do mundo adulto, essa participação dá-se de um modo específico e é representada em termos de usufruir dos benefícios presentes deste mundo como discotecas, barzinhos, festas noturnas e não de assumir as responsabilidades nele identificadas, como por exemplo, trabalhar, pagar contas, cuidar de filhos.

A identificação do estudo como sendo a principal atribuição na adolescência parece explicar-se por todos serem estudantes. No entanto, a significação atribuída ao estudo, como estratégia de preparação para a assunção de responsabilidades futuras, além de aparecer em todos os segmentos sociais e não haver diferenciação por sexo, parece assumir uma representação mais ampla que extrapola o universo dos sujeitos sociais pesquisados. Isto porque eles parecem não falar de si, mas de toda uma geração que necessariamente terá um devir. Por este ser "incerto", o adolescente deverá estudar para garantir seu espaço num mundo social marcado por diferenciações em termos de classes sociais, dada a progressiva parcela dos socialmente excluídos. Daí podermos observar que os adolescentes do segmento social A vêem no estudo a manutenção do seu status social, enquanto que os adolescentes dos segmentos sociais B e C, a possibilidade de ascensão social.

Vale destacar que a questão da realização profissional da mulher está igualmente presente, em nível do discurso. Se, em um primeiro momento, esta começa a trabalhar para complementar o salário familiar, hoje, a preocupação feminina, principalmente para a mulher do segmento social A, parece estar centrada na sua realização profissional, o que é evidenciado no depoimento a seguir:

"Eu estudo, faço inglês, estou pensando muito no que eu vou fazer no vestibular, eu queria fazer direito mas não vou fazer mais, agora eu tô na cabeça que eu quero fazer engenharia genética, só que no Brasil eu não tenho espaço para fazer isso, então eu vou ter que fazer uma coisa, eu não quero uma coisa que me dê dinheiro não é isso, porque eu não vou ser feliz só pelo dinheiro, eu não penso assim, sendo rica, eu quero uma coisa que me realize profissionalmente, eu tô estudando sobre esse assunto" (Ana 16 anos).

É interessante observar essa clara diferenciação observada na análise dos discursos das adolescentes. Parece que as adolescentes do segmento social A começam a desencadear uma ruptura das explicações biologizantes para a diferen- ça entre a divisão de trabalho masculino e feminino, ou seja, o trabalho masculino tende a ser o que traz a realização profissional e o status social, enquanto que o feminino repousa na ajuda da manutenção familiar. Reconstroem, portanto, o modelo das relações sociais, estabelecidas até 0 presente, que imprime nestas relações, como coloca FOUCAULT (1994), a questão do poder e da dominação, submissão e opressão. Neste sentido é que KERGOAT (1996) argumenta que as relações existentes também entre os segmentos sociais imprimem conteúdo e direção concreta às relações sociais de sexo.

Por outro lado, este tipo de preocupação não aparece nos depoimentos das adolescentes do segmento social C, revelando, ao que parece, níveis de significações diferenciados em função do papel que o mundo do trabalho representa para as mulheres de classes sociais distintas, ou seja, às primeiras pertencentes a classe alta, as possibilidades de realização profissional; às demais pertencentes as camadas populares, as possibilidades de inserção no mercado de trabalho como estratégia de sobrevivência e também de ascensão social.

No contexto do discurso adolescente a relação entre educação e trabalho assume dimensão relevante. À medida em que há a assunção da responsabilidade, através do estudo, aparece a preocupação com a definição profissional, sendo esta uma das grandes angústias da adolescência, pois, ligado a escolha da profissão estão os projetos de vida e perspectivas de participação no mundo social. Isto porque, a profissão pode representar tanto uma "garantia" de status, como de dada condição econômica.

Apesar de todos os adolescentes entrevistados acreditarem que é através do estudo que são definidas suas possibilidades concretas de existência, os pertencentes ao segmento social A o percebem como via para a alta qualificação, introjetando a importância e a necessidade de ingressar na universidade, para alcançar suas metas, refletindo a realidade dos tempos atuais que não só valorizam mas impõe ao adolescente de classe mais privilegiada a obrigação de cursar o $3^{\circ} \mathrm{Grau}$.

Os adolescentes dos segmentos sociais B e $\mathrm{C}$, que estudavam em escolas públicas tinham, por sua vez, a clareza de que sua perspectiva profissional apresenta condições diferenciadas, não explicitadas em termos das diferenciações de classe, mas traduzidas na qualidade do ensino a que os mesmos têm acesso. No entanto, em nível do imaginário, acreditam nas possibilidades de serem superadas as dificuldades, tendo em vista atingir objetivos a que se propõem. 
Mesmo para os adolescentes que trabalham, particularmente das camadas populares, as responsabilidades assumidas inerentes à sua atividade profissional são vistas de maneira relativa, não representando a ruptura da adolescência. A idéia presente é a de que no futuro um novo trabalho, "mais sério", mais profissional, caracterizará sua nova fase adulta, não atribuindo ao trabalho atual importância para a sua vida profissional futura.

Nesse sentido, o trabalho não assume grande significação nessa fase da vida, em termos de projeto futuro. Com relação aos adolescentes do segmento social C, não aparece a representação de que, pelo fato de necessitarem trabalhar e estudar à noite, além de sua própria condição de classe, o seu horizonte profissional seja limitado. A fantasia vivida por eles é que terão as mesmas oportunidades de outros adolescentes que só estudam e que, pela condição social, são mais privilegiados. Parece não haver a percepção dessa diferenciação, o que os faz sentir adolescentes com as mesmas expectativas de conquistar um projeto futuro melhor que o vivido atualmente.

\section{A Identidade de Gênero na Adolescência}

Ao pensarmos nos elementos constitutivos que configuram a identidade do adolescente é importante considerar os processos sociais e culturais que delineiam a construção da mesma, concebida, como afirmam LEAL \& BOFF (1996), como fator central do gênero e da sexualidade, tendo em vista a perspectiva de identificá-la em processo constante de mudança, como também nas suas implicações para a experiência da vida sexual. Neste sentido, ao abordar a questão de gênero é necessário partir das relações sociais de dada sociedade, e não simplesmente das categorias de feminilidade e de masculinidade como esferas estanques, dissociadas e sem relação uma com a outra, na sua própria constituição. Só assim é possível visualizar novos aspectos que as relações de gênero, emergentes na adolescência, encerram.

\section{O significado social do corpo}

Apesar de ser na infância que se começarn as primeiras identificações das diferenciações de sexo, para os quais comportamentos biopsicossociais são esperados e sancionados para ambos os sexos, é na adolescência que eles tomam forma e se definem em termos da estruturação das relações de gênero, uma vez que é neste momento que as concepções de masculinidade e feminidade passam a ter um significado próprio e são melhor delimitados. Para PARKER (1991), o corpo pode assumir um papel fundamental nesta relação, pois ele será o principal veiculador das práticas e comportamentos que expressam as relações entre homens e mulheres, pois através da linguagem do corpo, pela sua descrição e interpretação do mundo natural, é que é possível imprimir à realidade biológica uma dada significarão social.

Para HELMAN (1994), o corpo social é, então, parte importante da imagem do corpo orgânico por fornecer, a cada pessoa, uma base para perceber e interpretar suas próprias experiências físicas e psicológicas. Esse corpo, em profundas transformações na adolescência, passa a ter um significado mais relevante ainda, pois será através dele que haverá, ou não, a identificação com si próprio, com o grupo de pares e a percepção do olhar do outro.

Sendo o corpo um importante elo de identificação para os adolescentes, a preocupação com a beleza será marcante nesta fase, na medida em que ela propiciará a chance de se destacar no grupo. As mulheres passam a buscar o estereótipo da beleza através do corpo alto e esguio, copiado de modelos, artistas de cinema ou televisão, assim como o de formas bem delineadas e sensuais, como expressão do mito de sedução do corpo da mulher brasileira. Já os homens têm a preocupação em ter formas exuberantes, com tônus muscular bem definido. Essa busca de corpos esculturais representa a manifestação latente da simbologia do prazer erótico, capaz de despertar o desejo e o prazer no outro.

"Não tô satisfeita não, eu queria ser bem mais bonita, eu queria ser boazuda, daquelas muIheres que todo mundo mexe, passar na rua e todo mundo falar: nossa, que menina bonita!!! ... Preciso emagrecer, fazer ginástica, mudar um pouco as coisas ... é uma questão de vaidade, mas às vezes é só pra poder impressionar os meninos" (Branca/ 15 anos).

Não é possível analisar este fato descontextualizado do padrão de beleza "imposto" pela mídia, que atua primordialmente como formadora e reprodutora de estereótipos sociais, por exibir continuamente nos meios de comunicação padrões de beleza através do exibicionismo e culto público dos corpos de modelos e de atores, quase sempre desnudados, a partir dos quais reforça o "glamour anoréxico"4 do mundo da moda. Os adolescentes passam a ser o principal alvo desta idealização, pois utilizam seus corpos para chamar atenção sobre si.

4. Definição dada pelo Jornalista Marcelo Leite, na Folha de São Paulo, de 13/10/96. 
Essa idealização do corpo é notadamente marcante, independentemente do segmento social e sexo. Esse fato pode estar apontando para o papel fundamental dos meios de comunicação de massa na homogeinização de estilos de vida característicos das sociedades modernas. O corpo tem sido utilizado como um importante veículo de consumo, do tênis ao corte de cabelo, criando uma cultura de consumo que tem no adolescente um dos principais alvos de interesse.

Tratando da questão MORIN (1986) coloca que a cultura adolescente juvenil participa da cultura de massas, que é a do conjunto da sociedade, integrada na indústria cultuial, capitalista, que funciona segundo a lei de mercado, tornando-se um dos ramos do sistema de produção-distribuição e consumo que funciona para toda a sociedade. Porém, atua de forma mais intensa na adolescência, levando-a a consumir produtos materiais que incentivam os valores da modernidade. Moças e rapazes não são mais separados, um gosto comum conduz à cultura juvenil, levandoos a adotar os valores da civilização urbana essencialmente ligados às vestimentas e à diversão.

O corpo parece ser o principal veículo de diferenciação entre homens e mulheres em uma dada sociedade e a maneira de percebê-lo tornase diversificada conforme os gêneros. Tais diferenças, sendo construídas através de um processo social e histórico era de supor que as mesmas fossem percebidas de maneira diversificada no interior da sociedade havendo, portanto, uma diferenciação de tais concepções conforme os segmentos sociais, a religião, a raça, a idade e demais categorias nas quais possam ser estratificadas. A implicação deste fato poderia apontar, como coloca LOURO (1996), para o reconhecimento da existência de uma identidade para cada um desses pólos, acreditando no rompimento da unidade, ou seja, na impossibilidade de existência de apenas uma identidade masculina ou feminina, transformando em muitos ou em múltiplos o sujeito masculino ou feminino.

Para o grupo estudado, no entanto, parece que essas concepções não apresentaram diferenciações nem por sexo, nem por segmento social, podendo indicar que o corpo é um forte elo de ligação entre os adolescentes, umas das condições centrais que os transforma em um mesmo grupo.

A auto-estima relacionada ao corpo é fundamental neste processo, pois vai interferir no próprio desejo sexual, bem como na forma pela qual o adolescente percebe como pode ou deve atuar perante si e em relação ao outro. As escolhas amorosas passam a ser, muitas vezes, norteadas pelos atributos físicos, pouco importando o jeito de ser do companheiro como um todo. Nes- te sentido a estatura, beleza, contorno corporal do adolescente podem afetar o modo de como ele se vê e como as outras pessoas o sentem ou se relacionam com ele. À medida em que o adolescente não se aceita fisicamente, dificilmente se sentirá bem em relação a si mesmo e ao seu próprio corpo, dificultando a sua valorização pessoal, fazendo com que nunca se sinta desejável ou atraente.

\section{O olhar sobre o outro}

O “outro”, que até então era só visto comc amigo ou amiga, de forma aparentemente assexuada, passa a despertar a atenção, a provocar sentimentos de desejo, promover novas sensações, emoções, identificadas com formas de manifestação explícitas da sexualidade representada por diferentes matizes. Um aspecto que chama a atenção é o de que as adolescentes dos segmentos sociais B e $\mathrm{C}$ foram as que tiveram mais desenvoltura para falar sobre a questão, o que parece apontar para o fato da mulher, independente do segmento social, estar abrindo espaço na busca do exercício da sua sexualidade. Sendo estas as mais reprimidas pela sociedade vale lembrar que é, através do movimento feminista, que se instaura no seio das classes dominantes, no início das primeiras décadas da segunda metade deste século, a busca de liberdade de expressão da mulher para seus sentimentos e de igualdade de direitos. Nesse processo é que as próprias relações de gênero, reinterpretadas, atualizamse no interior da sociedade moderna permitindo, com isso, haver ampliação do processo a todos os segmentos sociais.

"Você começa a compartilhar momentos com outra pessoa, não uma relação de amiguinha assim, com um homem ... quando a gente vê um menino passando na rua e já começa a ligar, porque antes era só colega, você começa a achar mais defeitinhos numas coisas que já não tem, quando você é criança você não tem noção destas coisas" (Camila/16 anos).

Neste contexto, aparece como necessidade a busca das relações afetivas. Na representação das adolescentes entrevistadas é neste momento que a opção sexual pode ser tanto em relação ao mesmo sexo, como em relação ao sexo oposto. Da mesma forma, as adolescentes dos segmentos sociais B e C têm a percepção das possibilidades de existência de relacionamentos tanto homossexuais, como heterossexuais.

Numa fala caracteristicamente cifrada, lacônica, permeada de vazios, os adolescentes masculinos identificam apenas a necessidade de busca pelo sexo oposto. A preocupação com a afirmação da própria masculinidade parece estar presente neste fato, uma vez que a verbalização da possibilidade de existência de relacionamentos ho- 
mossexuais, poderia sugerir o medo velado dando diferenciação entre o discurso e a realidade, podendo esta posição ser interpretada como sua própria opção sexual. Daí, ao que parece, a negação em falar sobre o assunto, demonstrando que o mesmo é ainda polêmico, independente do segmento social a que o adolescente pertença.

Vale considerar, ainda, que exteriorizar a existência da atração sexual pelo mesmo sexo pode estar sendo bloqueada em função das dificuldades ainda existentes na aceitação das relações afetivas entre pessoas do mesmo sexo, pois, a despeito dos avanços da sociedade moderna, os valores e as normas sociais tradicionais ainda discriminam a homossexualidade apesar de na atualidade, observamos uma maior liberdade de expressão pública das relações não heterossexuais.

\section{O significado do namoro e do "ficar" na configuração das relações de gênero}

O relacionamento afetivo é fundamental para que se estabeleça identificações para a formação da identidade adolescente, pois é através dele que se experimentam relações de companheirismo, determinando como se comportam numa relação a dois, havendo trocas e experiências íntimas, com ou sem experiências sexuais. A curiosidade, a atração sexual e o desejo intensificam-se possibilitando a oportunidade de estabelecimento de relacionamentos amorosos que podem ser considerados eventuais ou duradouros, havendo diferenças entre um e outro, por apresentar importantes variações na forma de como se comportar e se relacionar a dois.

Os relacionamentos eventuais tomam forma, na linguagem do jovem, com o "ficar”, não havendo vínculo pessoal ou mesmo um compromisso duradouro. É uma fase de busca de experimentação sendo, às vezes, considerada uma fase intermediária para o namoro, que representa uma forma de compromisso mais duradoura. É interessante observar que apesar do "ficar" ser muito comum atualmente, esta forma de experimentação é carregada de preconceito não só entre os adultos, mas pelos próprios adolescentes havendo, claramente, uma distinção das possibilidades do "ficar" masculino e feminino. Para os adolescentes masculinos o"ficar” com várias meninas é aceito e muito incentivado. Nesse sentido, quanto mais ocorrer este tipo de relacionamento, mais o adolescente é valorizado perante o grupo, perante os pais e a sociedade, por marcar claramente seu poder de virilidade. Já para as adolescentes, tal situação assume conotações. Se elas estabelecem com freqüência esse tipo de relacionamento, serão consideradas "mulheres fáceis", sendo discriminadas não só pelos meninos, mas pelas próprias adolescentes. Apesar de ainda existir diferenciações na forma de se relacionar, tanto para o homem quanto para a mulher, relacionamentos polígamos são aceitos com naturalidade, pois não se espera que o adolescente, ao "ficar”, se mantenha fiel, podendo ser natural "ficar" com vários adolescentes em uma mesma noite.

Sendo o namoro considerado uma forma de relacionamento mais estável, os adolescentes criam expectativas diferentes neste tipo de relacionamento, firmando, em termos de representação, um pacto de fidelidade e sinceridade que permeia as relações amorosas. Pelo significado atribuído, este tipo de relação amorosa pressupõe reciprocidade no gostar, pressupondo também a existência de amor de ambas as partes. Os adolescentes masculinos identificam esta postura como sendo importante não só para o sexo feminino, mas para si próprios, o que pode estar representando a flexibilizarão da concepção machista em relação aos padrões e papéis tradicionalmente pré-estabelecidos do ser homem e mulher. A fidelidade, que sempre foi considerada um atributo da chamada condição feminina, começa a ser re-significada na relação afetiva. Observamos não somente a cobrança social da manutenção da fidelidade masculina, mas a própria necessidade de valorização deste tipo de relação através do respeito ao compromisso assumido não só pela mulher, mas também pelo homem.

E inegável, porém, que apesar da existência de resistências para que o jogo de sedução seja uma característica própria do papel masculino, a mulher tenha procurado criar um ponto de igualdade nos relacionamentos afetivos.

"Eu sempre gostei muito de namorar, ter amigos, sair, mas o que eu gosto mesmo é de namorar. Hoje em dia as meninas de 14 anos já estão namorando, elas querem mais é começar a sentir prazer logo cedo, melhor se tiver namorando" (Cristina/ 19 anos).

As questões referentes ao tipo de relacionamento estabelecido pelos jovens parecem também apontar para uma forma de homogeinização do comportamento adolescente. Se nos anos sessenta e setenta apresentam-se as possibilidades de maior liberdade de expressão para as mulheres das classes econômicas mais privilegiadas, uma vez que estas não somente tiveram mais acesso às informações, à educação e ao mercado de trabalho, mas também foram partícipes do movimento feminista, nos anos noventa, esta tendência parece apresentar-se para as mulheres de outros segmentos sociais, o que implica na ampliação de mudanças radicais nas formas de relacionamento entre homens e mulheres. Assim, o que se observa é que não só as mulheres, independente do 
seu segmento social, têm procurado vivenciar melhor os seus desejos e emoções, como os homens têm procurado estabelecer novas relações amorosas o que, de certa forma, muda essencialmente as relações de poder e de submissão entre os sexos, características das tradicionais relações de gênero (FOUCAULT, 1994).

\section{A ritualização da menarca em oposição à ejacularca}

A menarca assume papel importante nesta fase de socialização, pois ela continua sendo um marco que identifica a passagem da infância da menina para a adolescência. Muito valorizada pelas mães, ainda continua sendo atribuído um valor importante pelas adolescentes. Menstruar é tornar-se "mocinha", ou seja, é adquirir um novo status perante o grupo e a família. E um momento esperado ansiosamente pelas meninas havendo mesmo uma certa competição entre elas, criando uma expectativa de quem ficará menstruada primeiro e quando o fato acontece, é enaltecido para todo o grupo social da adolescente.

E interessante notar que para os adolescentes masculinos a menarca também tem a mesma dignificação, uma vez que reconhecem igualmente este poder de mudança de status.

"Com a menstruação a mulher começa a ver coisas diferentes, começa a entrar em outra fase da vida" (Bruno/ 18 anos).

A chegada da menarca constitui-se, portanto, em importante elemento definidor da passagem da infância para a adolescência para todas as adolescentes, independente do seu segmento social, caracterizando-se como um dos poucos ritos de passagem que ainda permanece valorizado nas sociedades modernas.

A menarca, ao ser valorizada como possibilidade de a menina tornar-se "moça", define claramente o espaço no qual a mulher poderá transitar, ou seja, esta mudança social do status de mulher pode, indiretarnente, ser considerada como um marco de atenção específica aos comportamentos futuros da menina-moça associada, sobretudo, conforme o observado, à preocupação com a fertilidade feminina. Daí, o significado social da repressão ao comportamento liberalizado da mulher consubstanciado na busca de controle do exercício da sua sexualidade. No âmbito dos discursos observamos que as adolescentes têm a "consciência” de que ao menstruar passam a correr o risco de ficarem grávidas devendo, por isso, preocupar-se com esta possibilidade.

"Fica todo mundo com aquela expectati$v a$, a minha mãe chorava, a minha filha ficou mocinha, claro que eu sabia que a partir daí eu podia engravidar" (Andreia!18 anos).
Já a ejacularca, para o adolescente masculino, não tem a mesma simbologia da menstruação, ou seja, possibilitar a mudança do status infantil para a adolescência, como ocorre para a menina. Observamos, pelos discursos, que os adolescentes masculinos quase não se lembram da primeira vez que ejacularam e as meninas nem fazem menção a esta questão não parecendo, portanto, uma identificação de passagem da infância para a adolescência.

Não será, portanto, a primeira ejaculação, mas a possibilidade de ejacular um marco importante dessa passagem, pois estará ligada à noção de liberação para o início da atividade sexual ativa. Estará intimamente ligada à noção de virilidade, de poder concretizar o ato sexual. Nesse sentido parece constituir-se como um marco não do início da adolescência propriamente dita, mas sim da afirmação da masculinidade do homem como parte característica do processo de adolescer. Esta significação dada a ejacularca foi percebida nos trềs segmentos sociais, podendo estar representando que este símbolo cultural existente em relação ao sexo masculino e associado à hierarquização das práticas sexuais, ainda conformam o poder masculino em relação ao feminino.

"Com a ejaculação vai achar que está sendo homem, que agora vou transar com uma menina, quer pegar, olha aquela menina e fica desesperado" (Carlos/16 anos).

Em contraposição, a visão das adolescentes é que a ejaculação é encarada como a possibilidade de liberação para a atividade sexual não sendo associada, em momento algum, à fertilidade masculina, denotando que a preocupação com a ocorrência da gravidez ainda é uma questão feminina, não havendo, portanto, para o adolescente, a necessidade de regular os seus impulsos sexuais, muito pelo contrário, eles devem ser liberados, pois fazem parte da condição masculina.

Interessante observar a identificação diferenciada, segundo sexo, entre os adolescentes, em relação ao significado da primeira ejaculação. Enquanto que para os meninos significa um fato biológico aparentemente banal e natural, o mesmo não ocorre com a representação social que as meninas têm dele. Isto porque, passam a identificá-la quase como um marcador da manifestação das relações de gênero, por implicar a liberação do poder masculino socialmente observado em relação a sexualidade, em detrimento do feminino.

(Os meninos dão importância a primeira ejaculação?)

"Eu acho que eles dão muito mais importância do que as meninas [comparando a primeira menstruação], eles pensam agora que eu virei homem, agora eu posso, porque menino leva 
muito mais a sério esse negócio, então eles acham que vão poder sair por aí transando com Deus e todo mundo e eles passam a só pensar nisso, eu vejo pelo meu irmão, quando ele passou por essa fase ele só pensava em sexo, que coisa chata, chata não, mas precisa ver que a vida não é só isso, os meus primos também, tem muito mais importância para os meninos do que para as meninas" (Andreia/18 anos).

(A l la $^{\mathrm{a}}$ ejaculação dos meninos tem a mesma importância que a $1^{\mathrm{a}}$ a menstruação para as meninas?)

“Tem mais, eles se sentem poderosos, os melhores. Eu acho que tem alguma coisa dentro deles que estimula eles a isso, da mesma forma que as meninas, mas com eles são mais, eles se sentem os melhores" (Ana/ 16 anos).

Este caráter precioso dado ao sêmen, que parece estar presente no imaginário dos adolescentes, é explicado por FOUCAULT (1994) através de sua interpretação sobre os textos de Hipócrates. O sêmen, mais do que ter o poder de dar a vida no ato sexual, ele proporciona ao homem um prazer mais intenso do que para a mulher porque a excreção do humor se faz de maneira mais abrupta e com muito mais violência, além do fato de o prazer da mulher, ao longo de toda a relação, ser dependente do homem. Isto porque mesmo quando ela chega ao orgasmo antes dele, o ato sexual só terminaria quando o homem a liberar. Daí, a desigualdade entre homens e mulheres na relação sexual poder ser explicada pelo fato do ato sexual ser entendido como expressão de superioridade "natural", pois é o macho que desempenha um papel incitador e dele deve sair vitorioso.

Neste contexto, o ato feminino não é considerado como complemento, pois é sempre dependente do masculino. A simbologia social deste poder encontra-se de maneira expressiva em FOUCAULT (1994, p. 118) quando afirma que "o ato sexual arranca do corpo uma substância que é capaz de transmitir a vida, mas que só transmite porque ela própria está ligada à existência do indivíduo e carrega em si uma parte dessa existência. O ser vivo, ao expulsar seu sêmen não se limita a evacuar um humor em excesso; ele se priva de elementos que são de grande valia para a sua própria existência”.

\section{A Re-Construção dos Valores Sexuais e seu Papel na Identidade de Gênero}

A sexualidade pode ser pensada a partir de uma esfera na qual são construídas e transformadas as relações sociais, culturais, e políticas através dos diferentes valores, atitudes e padrões de comportamento existentes nas sociedades modernas.
Os tabus, sendo considerados proibições absolutas, geralmente revestem-se da função social de preservar as instituições vigentes. Ao começar a experimentar sua sexualidade, o/a adolescente depara com alguns questionamentos, por exemplo, em relação a masturbação, ao homossexualismo, a virgindade, sendo estes considerados como importantes tabus, uma vez que funcionam como "reguladores" dos comportamentos sexuais, principalmente neste fase da vida.

Estas pautas, como aponta BARBIERE (1993, p.83), darão um contorno a “construção dos sistemas de gênero que correspondem à totalidade dos arranjos através dos quais as sociedades transformam a sexualidade biológica em atividades humanas, a partir das quais as necessidades humanas são satisfeitas, quanto transformadas. O poder contido nos sistemas de gênero opera com mais força nos estágios reprodutivos da vida humana quando os meios para controlar a sexualidade, a reprodução e acesso às atividades produtivas estão situados e funcionam de maneira mais aguda. Esta definição favorece a desconstrução das diferenças de gênero que foram e continuam a ser reinterpretadas, racionalizadas como resultado de uma ordem natural e biológica imutável, no sentido de pensá-las como circunstâncias construídas social e historicamente e, portanto, sujeitas à transformação pela ação social e política. Essa compreensão de gênero como um operador social e simbólico também possibilita o exame das relações de poder inter e intra-gêneros”.

A sexualidade, portanto, dada a ampla gama de situações e múltiplas implicações sociais, constitui-se um objeto de controle ideológico de amplo aspecto. Daí, segundo PORTILLO (1992), adquirir caráter social normativo, indicativo do que seja normal ou patológico. Esse caráter normativo, porém, não é homogêneo para todas as sociedades, sendo que o próprio conceito de normal e patológico pode variar de cultura para cultura, ou mesmo de um período histórico para outro. É neste sentido que Portillo afirma que os valores como heterossexualidade, monogamia, fidelidade conjugal, sexualidade orientada para a reprodução, virgindade, entre outros, variam de acordo com as diferentes culturas ou mesmo através da evolução destes conceitos numa mesma sociedade.

Deste modo, os papéis sexuais determinam a forma como as relações de gênero se estruturam, determinando padrões de comportamento típicos para homens e mulheres. Esses comportamentos começam a ser reconhecidos ainda enquanto crianças, sendo que a partir da infância são estabelecidas condutas específicas para cada um dos sexos pretendendo-se com isso, imprimir identidades diferenciadas. 


\section{Re-significando a virgindade}

O processo de urbanização e de industrialização, neste último século, influenciou de maneira decisiva as transformações sociais da humanidade, teve um peso decisivo na nossa sociedade, a partir sobretudo dos anos 50. Sendo a sociedade brasileira tradicional caracterizada pela estrutura sócio-econômica predominantemente rural, até o fim do século XIX, conformada por uma estrutura patriarcal que definiu claramente o papel feminino e masculino como dicotômicos, o advento de uma sociedade urbano-industrial, nas últimas décadas, conformou características peculiares em termos da configuração das relações de gênero.

Dentre as mudanças comportamentais ocorridas nas últimas décadas, os padrões de comportamentos ligados à atividade sexual foram, sem dúvida, os que apresentaram maiores repercussões sociais, fenômeno este que vem se refletindo, principalmente, nas mudanças dos valores sociais da população adolescente.

A disseminação do uso dos métodos contraceptivos teve papel fundamental nesta mudança, pois permitiu à mulher o livre exercício da sua sexualidade, possibilitando haver uma separação entre a reprodução e o prazer no ato sexual, o que veio facilitar a existência de relações sexuais fora do casamento.

Em nível dos adolescentes entrevistados, o discurso presente foi coerente com esta mudança de visão sobre a virgindade, o que significa que para ambos os sexos ser virgem não é uma questão fundamental para a definição de seus relacionamentos afetivos. Assim, as evidências de uma clara mudança na concepção acerca da importância da mulher ter que se casar necessariamente virgem traz alterações substantivas para a construção da identidade feminina no mundo moderno.

Apesar da representação, em todos os segmentos sociais, de que a virgindade feminina não é mais valorizada como antigamente, sua re-significação apresenta diferenciações no interior dos mesmos e manifesta-se de forma velada. Os adolescentes dos segmentos sociais A e B afirmaram que para eles não há mais a preocupação em ter que se casar com uma mulher virgem, porém gostariam de ser o primeiro a ter relações sexuais com suas namoradas, o que não deixa de ser uma forma de valorização da virgindade feminina, embora desvinculada do casamento. Para adolescentes do segmento social C, no entanto, a virgindade aparece ainda como importante mas, o que acontece, na prática, é que na medida em que mulheres estão deixando de ser virgens mais precoce- mente, a aparente aceitação apresenta-se, de maneira velada, muito mais por falta de opção.

As adolescentes, no entanto, foram unânimes em revelar preocupação muito mais centrada nas expectativas da primeira experiência sexual do que na necessidade de continuarem virgens até o casamento.

Os pais parecem ter um papel marcante na construção das identidades de gênero da nova geração, pois continuam aceitando com naturalidade o início precoce da ativiclade sexual na adolescência para o sexo masculino e, muitas vezes, até incentivando, mas apresentam comportamento inverso em relação à adolescente. É importante ressaltar que nessa prática encontra-se exemplificada a perpetuação da relação existente entre gênero e poder, presente no discurso de FOU-CAULT (1994) sobre a sexualidade. A construção cotidiana do domínio masculino sobre o seu corpo, em detrimento ao da mulher, define claramente os conteúdos do ser masculino e feminino que estruturam o duplo padrão de moral de nossa sociedade; o primeiro - apresentando um caráter ativo, frente ao segundo - relacionado a passividade.

Enquanto a vida sexual feminina ainda sofre controles rígidos a todas as suas manifestações fora do casamento, por outro lado, a atividade sexual do homem continua permitida e encorajada demonstrando que as estruturas ideológicas do sistema patriarcal continuam influenciando os processos de socialização sexual, intimamentes ligados à questão do poder. Como coloca PARKER (1991), esse processo simultaneamente aumenta e legitima uma elaborada estrutura hierárquica na qual os homens se distinguem em termos de autoridade e domínio, ao passo que as mulheres se distinguem de acordo com sua submissão e sujeição ao jugo. Essa estrutura da hierarquia de gênero perpassa, ao que parece, a estrutura mais geral dos significados sexuais da nossa sociedade como um todo.

No universo dos adolescentes, no entanto, a re-significação do valor dado a virgindade assume outras matizes. Ou seja, ser virgem ou manter-se virgem é tido, também, como uma forma de diferenciar-se do grupo de pares, portanto, de não identificação com o mesmo havendo, inclusive, pressão para que a adolescente inicie sua vida sexual precocemente. Na medida em que a virgindade passa a ser “desqualificada”, a exigência pelos pais da adolescente para manter-se virgem carece de significado, principalmente quando o discurso jovem assumido na modernidade é o de que manter-se "pura” reveste-se da noção pejorativa de não ser desejada.

"Hoje em dia não dão valor [para virgindade] como antes, hoje em dia as pessoas são 
ridicularizadas se assumem a suá virgindade... não adianta você ir simplesmente com alguém só pra dizer para turma que não é mais virgem e você é a única da turma virgem, porque as pessoas acham que se ainda não transou é porque ninguém te quer" (Cláudiall5 anos).

Neste contexto, tornar-se atraente e de sejada passa a ser um importante valor feminino, havendo uma busca quase que frenética em torno da sensualização e do erotismo do corpo. À medida em que as relações sexuais não acontecem, elas podem estar sendo associadas diretamente a uma desvalorização pelo outro gerando, inclusive, uma insegurança de que o grupo faça esta identificação. Em contrapartida, a adolescente pressionada pela grupo de amigos a iniciar sua vida sexual, à medida em que isso não acontece, começa a sentir-se deslocada do grupo, distanciada, sem identificação, pois os assuntos sobre a atividade sexual que são discutidos nos encontro com os amigos passam a ser o grande elo de ligação entre as adolescentes.

Para os adolescentes, ser considerado moderno implica demonstrar que valores tradicionais sobre a virgindade devem ser rompidos para que se identifique a existência de transformações dos seus valores em relação aos do pais. Porém, a questão da perda da virgindade ainda reveste-se de ambigüidade no discurso dos adolescentes. Não ser mais virgem parece não ter importância para o estabelecimento de relações afetivas porém, de forma velada, o que alguns discursos parecem sugerir é que, em nível do "inconsciente", a questão posta é muito mais da liberação da sexualidade feminina com múltiplos parceiros.

$$
\text { “” (César/18 anos). }
$$

\section{A "primeira vez": mito e fantasia}

A constatação de que o comportamento sexual do homem alterou-se no mundo moderno pode ser exemplificada pelo fato de seu primeiro relacionamento sexual ocorrer, na maioria das vezes, com a sua "namorada". Os jovens têm, então, iniciado sua atividade sexual com seus parceiros, muitas vezes, no primeiro relacionamento afetivo. Este ponto merece reflexão, pois aponta para algumas questões de mudança de comportamento sexual e afetivo da população adolescente com implicações para novas configurações das relações de gênero. Até há pouco tempo atrás, a realidade era muito diversa uma vez que as mulheres iniciavam sua atividade sexual geralmente com seus maridos ou com homens mais velhos. Os homens, por sua vez, tinham sua iniciação sexual com prostitutas ou, também, mulheres mais velhas. Geralmente, iniciavam mais precocemente sua atividade sexual em relação à mulher.
Na realidade, o que parece estar ocorrendo são novas possibilidades dos jovens buscarem parceiros com idades similares. Ou seja, a mulher tem antecipado o início da sua atividade sexual e o homem postergado, sendo no mesmo grupo de pares que se dá esta iniciação. Este fato representa uma mudança social significativa pelo estabelecimento de novos padrões de relações para a ocorrência da atividade sexual, ou seja, no caso da mulher descola-se do casamento para o namoro e no caso do homem, da prostituição para o namoro, o que parece reafirmar a relevância do mesmo no processo de adolescer.

Esse fenômeno pode ser identificado entre os adolescentes entrevistados, cujo início da atividade sexual ocorreu em situação pré-marital, com parceiros em idade similar, em torno dos 16 anos, não havendo diferenciação por sexo, nem por segmento social.

Relacionada ao deslocamento do eixo da primeira atividade sexual do homem, prostitutanamorada, poderia se imaginar a existência de uma mudança de comportamento no tipo de relacionamento dos jovens, ou seja, o primeiro ato sexual tanto para a mulher, quanto para o homem, sendo considerado como um momento de troca e de afeto, em decorrência da busca de complementariedade no relacionamento entre o casal.

No entanto, no relato acerca de como foi a "primeira vez", os discursos apresentam significações bastantes distintas para cada um dos sexos. Para alguns adolescentes masculinos, o início da atividade sexual ainda é visto como a possibilidade de ascensão perante o grupo, a forma de demonstrar sua virilidade e a própria necessidade de iniciar a atividade sexual por ser uma condição exigida pela sociedade.

A virgindade masculina não deixou de ser vista como vergonha porque o medo de demonstrar a falta de experiência, de não poder se expor perante à mulher e até mesmo perante 0 grupo, além da necessidade de valorização da virilidade do homem, demonstram que a noção de masculinidade, fundada a partir dos valores da sociedade patriarcal, ainda está presente na vida do jovem atual, e é reiterada pelas tradicionais expectativas de comportamento constitutivas das relações de gênero, ainda vigentes em nossa sociedade.

É interessante observar que, apesar das adolescentes do sexo feminino também considerarem que a virgindade não mais se apresenta como elemento importante e condição "natural" para o casamento e certificado de sua moralidade, o início da atividade sexual antes do casamento permanece cheio de expectativas, idealizado como um acontecimento romântico, especial e mitifica- 
do a partir de fantasias de que a 'primeira vez “ seja a possibilidade de viver um conto de fadas.

"Eu não sou romântica, mas nessas horas eu costumo ser um pouquinho mais do que o costume, eu sou meio prática, mas nessa hora que a gente precisa de um carinho, de um afeto, de palavras bonitas, eu não lava esperando amor dele, só carinho lava bom ... eu esperava uma coisa de filme! (Branca/ 15 anos).

Possivelmente esta fantasia seja a forma encontrada pela mulher para substituir a primeira relação sexual pela “noite de núpcias”, ou seja, essa iniciação continua mitificada, embora oculta, pelo processo de ritualização que valoriza a primeira noite da mulher, quer após o casamento ou não. Acreditar na existência de um momento mágico aproxima-se da idealização de que a mulher viverá uma grande história de amor, semelhante aos contos de fadas, o que parece explicar porque muitas adolescentes buscam adiar sua iniciação sexual na esperança de que ocorrerá uma “transa” muito especial.

\section{Os primeiros parceiros: escolha ou acaso?}

Outra questão relevante sobre o início da atividade sexual é a questão da escolha do primeiro parceiro. Apesar do adolescente do sexo masculino não buscar mais iniciar sua atividade sexual com prostitutas, não há a valorização de que o primeiro ato sexual seja necessariamente com uma pessoa com que tenha um grande envolvimento afetivo. "A primeira vez é aprendizado, tem empurrão dos irmãos ou amigos que são mais velhos... sempre acaba rolando, independe de com quem, com a empregada a prostituta ou a namoradinha, tanto faz, eu nunca tive fantasias, isso é coisa de mulher se você vai agradar, tanto faz, é uma loucura" (Ademar/19 anos).

No entanto, esta parece ser a grande pre ocupação das adolescentes; a idealização de primeira relação sexual como algo de grande significação para a mulher explica porque a escolha do parceiro terá grande relevância neste processo. Essa ainda demonstra uma postura conservadora com relação a sua opção em es colher o seu parceiro. A concordância em iniciar sua atividade sexual ainda está muito ligada â possibilidade de se estabelecer uma relação estável, de existência de um forte vínculo afetivo entre o casal.

Há também a preocupação da adolescente com o "gostar", valorizando a reciprocidade do sentimento. A idéia presente é a de que o menino goste muito da menina, que ele não queira transar só por transar. Para os adolescentes, no entanto, esta preocupação quase inexiste, pois os mesmos podem iniciar sua atividade sexual independente do tipo de relacionamento, ou seja, quer com a namorada, com amigas ou conhecidas.

"Eu quero que seja com um cara que eu goste muito e que ele goste muito de mim também, não quero só eu gostar dele e ele estar ali só por causa disso “"(Ana/16 anos).

E qual o significado desta escolha? O que vem a ser a pessoa certa? O que parece ocultar-se nessa escolha ideal, a despeito da virgindade não se constituir mais numa condição necessíária para o casamento, é o medo do abandono após o início da atividade sexual, ou até mesmo o medo do julgamento moral da sua conduta, o "ficar falada", pela possibilidade de contatos mais fáceis (sem a simbologia da primeira vez) com outros parceiros.

Neste sentido, a aparente ambigüidade observada na conduta feminina em relação a busca do primeiro parceiro sexual antes do casamento, ainda dentro de "moldes conservadores" de uma relação afetiva definida que lhe dê a segurança de não ser abandonada, pode ser explicada pela manutenção de resquícios na modema cultura paulistana e brasileira da dicotomia observada em relação ao papel feminino no sistema patriarcal que colocava à disposição do homem duas categorias sociais de mulheres: de um lado, a esposa, que só iniciava a atividade após o casamento, cujo exercício da sexualidade era especialmente ligado à questão da procriação e, de outro, a amante ou concubina voltada à satisfação dos prazeres do homem (PARKER, 1991). Com a permanência de resquícios desses valores tradicionais impregnados no imaginário feminino, a despeito dos avanços sociais da sociedade brasileira, é compreensível que as adolescentes de hoje busquem repousar sua primeira experiência sexual sobre relações afetivas que possam traduzir-se em compromisso futuro.

"Eu já conheci casos assim que as meninas de repente conheceram um cara e se sentiram apaixonadésimas, eles falam: a gente vai casar, vai continuar junto, transou, o cara foi embora $e$ pronto, elas ficaram super mal aí eu acho que não é legal, por isso eu quero ter muita segurança e gostar muito do cara e ele de mim pra isso não acontecer comigo" (Andreia /19 anos).

A persistência dos valores culturais do sistema patriarcal na sociedade atual pode explicar, igualmente, o fato de, a despeito dos adolescentes do sexo masculino passarem a valorizar sua iniciação sexual com garotas de sua idade, a mesma continuar revestida de antigas significações próprias da tradicional cultura machista. Ou seja, a valorização do primeiro ato sexual se dá em função da necessidade de se impor perante o grupo de amigos sendo, muitas vezes, valorizado pela família; consistir igualmente em um marco im- 
portante na vida do homem, no sentido de afirmar seu poder de macho, traço ainda marcante da antiga identidade masculina. Não ter relações sexuais significa, portanto, para o homem, não demonstrar esse poder que pode estar associado à condição de escolha pela homossexualidade, uma grande preocupação entre adolescentes entrevistados.

"Olha em relação ao homem tem um ponto que eu acho $X$ ele tem medo, quando ele é machista, quando ele é bem macho, o ponto fraco é chamá-lo de veado, por exemplo, ele detesta essa imagem dos outros pensarem que ele é homossexual, ele não aceita essa atitude das pessoas e condena quem pensar isso deles, tem quefazer logo pra não pensarem isso dele" (Cláudia/ 15 anos).

Os significados atribuídos ao início da atividade sexual continuam, assim, sendo completamente opostos para os dois sexos, em todos os três segmentos sociais, demonstrando que a liberação da atividade sexual para a mulher, apesar de ser uma realidade dos tempos modernos, ainda é cercada de preconceitos e restrições.

\section{Os medos: virilidade $\mathrm{x}$ dor}

Outra questão que se apresenta, com relação ao início da atividade sexual na adolescência, está relacionada aos medos que acompanham a expectativa desse primeiro relacionamento. Para as meninas, o medo da dor aparece como marcante para quase todas as entrevistadas, independentemente do segmento social a que pertencem. Para a maioria, este medo pode estar associado ao tipo de relacionamento e a própria insegurança da escolha do momento certo para o início da atividade sexual, parecendo estar simbolicamente presente a idéia da dor como uma punição ao estar cometendo um ato não permitido.

"A menina já vai lá achando que vai sentir muita dor, tem menina que acha que vai sangrar até ter uma hemorragia, tem umas que querem se casar porque transaram a primeira vez" (Bianca/ 17 anos). meira transa?)

(Tem alguma expectativa em relação a pri-

"Penso, mas não me preocupo muito. Pode ser que doa muito. Eu não imagino como possa ser, mas eu quero que seja com um cara que eu goste muito e que ele goste muito de mim também, não quero só eu gostar dele e ele estar ali por estar, pra eu não me arrepender depois, porque ainda hoje é complicado começar a transar" (Ana/ 16 anos).

Por outro lado, é interessante observar que à medida em que a adolescente se sente segura da sua decisão, por se encontrar numa relação está- vel, ela não manifesta preocupação com o medo da dor na primeira relação sexual o que parece apontar para o fato deste medo aparecer em decorrência da própria insegurança do que vai acontecer após o ato sexual, de como vai ficar o seu relacionamento com o parceiro. É enfim, a insegurança emocional de ser abandonada ou vir a se tornar "mal vista" pela sociedade.

(Você acha que foi na hora certa?)

"Eu acho que sim, porque foi com uma pessoa que eu amei muito, não me arrependo, não tive medo dele me largar por causa disso. A gente se separou depois porque não tinha mais a ver, acabou" (Beatriz/16 anos).

Para os meninos o medo característico que se apresentou para quase todos os entrevistados, foi o de "falhar" na primeira vez, reforçando que a concepção do mostrar-se viril perante a mulher é, ainda, um traço relevante na identificação da masculinidade, demonstrando que esta questão é comum entre segmentos sociais analisados. A ocorrência de impotência sexual na adolescência é um fato raro. O significado do medo de falhar pode ser interpretado como o medo da ejaculação precoce, este sim, um evento que se apresenta com freqüência neste período. Como ao ejacular precocemente, interrompe-se o ato sexual de maneira abrupta, a possibilidade dessa ocorrência traduz-se em medo, podendo ter a mesma significação da perda da virilidade.

"O que mais preocupa o homem, acho que a maioria tem que fazer muito rápido, rápido que eu falo é idade, por medo ... medo de que falem dele ou coisa parecida, porque vai ficar brocha, a maioria pensa assim" (Bruno/18 anos).

E interessante observar que nenhuma das adolescentes entrevistadas referiu como motivo por ainda não ter tido relações sexuais a preocupação com os valores impostos pela religião. Sendo um importante aparelho repressor do comportamento sexual, a Igreja, ao que parece, tem diminuído cada vez mais seu poder de ditar normas e valores morais, principalmente para os adolescentes, uma vez que estes estão se distanciando dos cultos religiosos.

SAKAMOTO et al. (1988) aponta, em seu estudo, que a falta de religião pode ser associada à prática da relação sexual “pré-marital” para os adolescentes. No grupo feminino, a taxa mais alta desse tipo de relação é encontrada para as jovens que referem não ter religião $(53,4 \%)$, ou as que são católicas e freqüentam cerimónia menos de uma vez por mes (47,0 \%). WHITE \& DEBLASSIE (1992) corroboram esta idéia; ao realizarem uma análise da literatura sobre a sexualidade do adolescente, num período de cinco anos, afirmam que a religião é um importante agente de sociali- 
zação e que desencoraja a atividade sexual precoce, na medida em que vários estudos demonstram haver uma significativa correlação entre o comportamento sexual do adolescente e sua formação religiosa.

\section{Re-significando a prevenção da gravidez, das DST's e da AIDS}

O controle da fecundidade ou a prevenção das doenças sexualmente transmissíveis talvez seja uma das principais formas de controle social sobre a mulher e, por outro lado, um dos eixos condutores da luta dos movimentos feministas, que aponta para a existência das desigualdades sociais entre homens e mulheres relacionadas a questão de controle e poder sobre o seu corpo, perpassando, assim, discussões sobre reprodução, anticoncepção e aborto.

Pensar na utilização de métodos contraceptivos significa enfrentar questões anteriores a esta decisão, que envolve desde a autopermissão até o enfrentamento da família, atreladas ao tipo de relacionamento a ser estabelecido com o parceiro.

O sentimento de culpa que surge após o início da atividade sexual, reforça a necessidade do enfrentamento dessas questões de gênero, ainda tão longe de serem resolvidas, apesar de todo o avanço vivenciado pelas sociedades modernas. A insegurança de ser abandonada traduz o primeiro elo destes questionamentos. O modelo ideológico que representa a submissão da mulher na relação com o homem continua a exercer profunda influência na maneira de agir, pelo menos no início de relacionamento homem-mulher. Por outro lado, o medo constante do homem falhar na primeira experiência também demonstra a necessidade de superar-se na relação sexual, no sentido de ser melhor, mais experiente, portanto, de não ficar na condição de inferioridade perante a mulher, o que significa a manutenção da relação de poder neste momento. Pensar na anticoncepção significa a possibilidade de troca, de re-significação desta relação de poder, de inferioridade e superioridade.

"Eu acho muito difícil usar na primeira vez, porque você não tem liberdade de pegar a camisinha, tem gente que acha que quebra o clima ... não tem aquela preparação ... o homem ainda tem preconceito da mulher pedir pra usar, é como se ela tivesse muita experieência e eles não gostam disso" (Aline/19 anos).

"É muito difícil usar a camisinha na primeira vez. Sente aquela necessidade e vai sem nada, fica muito ansioso, não pode demonstrar pra mulher que tá nervoso" (Bernardo/16 anos).

À medida em que a família não autoriza as jovens a iniciar um relacionamento sexual ainda solteiras, o local onde ocorre a primeira relação também tem uma enorme influência nesta complementariedade do casal. A falta de segurança, o temor de aparecer alguém no momento introduz na relação sentimentos de ansiedade, culpa, pressa, desejo que se misturam o que descaracteriza qualquer possibilidade dos mesmos em relação ao uso do preservativo, fato esse igualmente observado por GASTON et al (1995).

Com o advento da AIDS, o uso da camisinha é associado de maneira significativa à sua prevenção, não havendo, no entanto, a valorização de sua utilização como método contraceptivo ou mesmo preventivo às demais doenças sexualmente transmissíveis. POPPEN (1994) afirma que o condom é o método mais usado na primeira relação sexual e que, sem dúvida, as extensas campanhas publicitárias sobre a disseminação da AIDS contribuíram para a adoção deste método. Essa parece ser também a realidade brasileira.

O espaço aberto nos meios de comunicação para a discussão da importância do uso da camisinha na prevenção da AIDS tem repercutido muito em toda a sociedade e parece que está começando a mudar o comportamento dos jovens, o que foi evidenciado nos três segmentos sociais.

"Estão se prevenindo só por causa da AIDS, se não fosse, eles não tariam nem ligando" (Bárbara/ 17 anos).

A despeito de tais evidências, algumas considerações merecem ser feitas, pois o uso da camisinha tem implicações bem mais complexas do que outros métodos contraceptivos. Utilizar a camisinha como método contraceptivo significa dividir a responsabilidade da anticoncepção que, até então, era atribuição exclusiva do papel feminino.

"Primeiro que eles deveriam conhecer todos os métodos anticoncepcionais né, no caso da gravidez, a menina tem que tá usando pílula e no caso da AIDS tem sempre que tá usando camisinha.

(E você, o que fará?)

Sei lá não faço a minima.

(Mas você não disse que precisa conhecer todos os métodos?)

É mais isso é mais coisa de mulher.

(Você acha que não tem que se preocupar??

É. Com a AIDS, a gente tem que se prevenir" (Baltazar/ 15 anos).

Um dos discursos ainda muito utilizado para o não uso da camisinha é que o método atrapalha o prazer do ato sexual, sendo expresso popularmente na tão conhecida frase "chupar bala com papel”. Esta conotação dada a camisinha está diretamente ligada à própria noção de masculinidade que ainda faz parte do universo cultural do adolescente brasileiro. O "tirar o prazer" significa, como coloca PAIVA (1994), racionalizar ou 
regrar seus impulsos sexuais, ter que considerar a parceira, portanto, trair sua virilidade, pois o ser homem é naturalmente ter menos controle de seus impulsos sexuais e de forma agressiva, com mais intensidade do que a mulher. Para a mulher, sair do seu papel feminino passivo prescrito, é mostrar-se familiarizada com aquilo que deveria ser desconhecido.

O que chama a atenção neste fato é que, apesar do jovem ter "consciência” da necessidade do uso da camisinha, parece que o seu uso transcende a questão puramente lógica e racional. Isso porque, de conformidade com análise anterior, a despeito da existência de uma maior percepção da importância do seu uso, a concretização do mesmo implica questões muito mais complexas, que ultrapassam o nível do comportamento individual, decorrentes da forma de organização social e cultural de nossa sociedade e, como foi evidenciado em nível dos discursos, trata-se de uma questão marcadamente presente no interior dos diversos segmentos sociais aqui analisados.

Nesse contexto, o uso da camisinha, pode apresentar-se como a possibilidade da existência de igualdade numa relação. VAUGHIN et al. (1989) afirmam que as razões citadas pelos adolescentes para que os mesmos não utilizem o condom são a necessidade de interrupção do coito, a diminuição da sensibilidade peniana durante a penetração, a associação feita com possibilidades de existência de doenças sexualmente transmissíveis ou de promiscuidade da parceira, além da questão do homem não assumir a responsabilidade na contracepção. Historicamente, o homem não tem participado da contracepção, sendo uma responsabilidade feminina. Em contrapartida, o uso do condom tem sido uma atribuição do homem e a mulher exclui-se da responsabilidade na sua utilização. As falas seguintes, reforçam o padrão de comportamento no qual a negociação para o "sexo seguro" ainda é uma questão difícil de ser enfrentada, uma vez que as mulheres exigem menos o uso da camisinha, principalmente nas relações estáveis, e a tendência a usar a camisinha nas relações casuais ou com menos vínculo afetivo é reconhecidamente maior.

Não podemos, no entanto, como discute PAIVA (1994) desvincularmos desta falta de negociação a questão da mitificação da camisinha como um método não eficaz para a prevenção da gravidez, bem como a identificação da pílula como tal, sendo veiculados durante décadas pelos profissionais de saúde, pela média e pelo movimento de mulheres.

"A camisinha incomoda e tem o fato da pressa... é importante mesmo a menina ir ao gi- necologista e tomar a pílula, a menina tem que tá usando a pilula.

(E se a sua namorada exigisse pra você usar a camisinha?)

Eu não ia querer saber mais dela, é ela que tem mais é que se cuidar.

(Mas em relação a AIDS, você não acha que também tem?)

Mas usar camisinha é que nem chupar bala com papel, prefiro arriscar “ (Bento/18 anos).

Outra questão importante na utilização dos métodos contraceptivos é a auto-permissão, ou seja, iniciar uma anticoncepção responsável significa assumir a sua própria sexualidade e, muitas vezes, ter que assumir perante a família sua atividade sexual ativa.

Como a família não faz parte deste processo e há um enorme medo de que tal prática seja descoberta, pois se a família encontra uma cartola de pílula ou caixa do diafragma significa a prova concreta do exercício da sexualidade pela adolescente, a anticoncepção não é sequer pensada pela mesma. À medida em que o desejo e a vontade se intensificam, elas mergulham numa aventura e passam a aguardar ansiosamente a chegada da próxima menstruação.

E mesmo quando a gravidez não acontece, passado o susto inicial, elas continuam insistindo em não utilizar qualquer método. Essa postura pode estar indicando que, apesar da adolescente afirmar que a gravidez não faz parte dos seus sonhos imediatos, a vontade de testar a sua fertilidade ou mesmo o desejo inconsciente de ser mãe possa estar presente nesta atitude. A reconstrução de um novo modelo do papel feminino, no qual o ser mãe pode não ser a prioridade ou o principal projeto de vida da mulher parece, no entanto, ainda estar introjetado pelo modelo tradicional do papel feminino, em que ser mãe faz parte da existência de toda a mulher e a adolescente, então, vive um constante dilema, pois, apesar de cada vez mais buscar outras opções, este sonho pode, ainda, fazer parte da sua realidade.

"Eu tenho uma amiga que ela é louca, todo mês ela transa fica na maior ansiedade esperando ver se vem pra ela. Ai na hora do sufoco ela fala, agora eu vou me prevenir, mas no outro meãs é a mesma coisa, até a hora que ela engravidar, não se emenda mesmo" (Beatriz/ 16 anos).

A constante necessidade de viver situações emocionantes, estarem conseqüentemente expostos ao perigo, faz parte do processo de busca da auto-afirmação. Este fato pode também ser evidenciado pelo não uso da anticoncepção na adolescência.

O sentimento de onipotência, tão característico desta fase, pode ser evidenciado a partir 
da justificativa corrente de que "isso não vai acontecer comigo”. Desta forma, adquirir doenças sexualmente transmissíveis ou engravidar não é visto como uma conseqüência da atividade sexual não protegida, pois com eles isto não acontecerá, não havendo portanto, justificativa para o uso de anticoncepção na adolescência.

"E aquele papo de sempre comigo não vai acontecer nada nunca. O Darci, por exemplo, quando foi fazer exame no exército ficou morrendo de medo porque eu sei que ele teve relações com um monte de meninas, meninas que davam pra todo mundo na praia, eu morri de medo do exame, porque a gente tinha relação e nunca usou nada, apesar da gente saber que precisava" (Cristina/ 19 anos).

A racionalidade no uso da anticoncepção é encarada, muitas vezes, como a quebra da emotividade tão fortemente vivida pelos adolescentes. Racionalizar as emoções, não deixar que elas fluam com naturalidade, sem compromisso, podendo significar o rompimento do pacto de amor.

"Minha amiga engravidou, ai ela disse: ele também devia ter se prevenido, mas se naquela na hora ele parasse e dissesse eu vou usar camisinha, então ia achar que não era paixão, porque paixão é um negócio que te tira do sério" (Ana/ 16 anos).

Pensar em anticoncepção representa o desejo concreto de não querer engravidar, portanto, estar certa de que o desejo de ser mãe deva ser adiado para outro momento da vida. Se o tradicional papel feminino atingia sua plenitude com a gravidez, pensar no adiamento desta para um momento posterior, é uma decisão que representa muito mais do que postergar um sonho, significando uma mudança na postura feminina diante da sociedade, isto é, ter outros sonhos em que a gravidez não está presente como a profissionalização da mulher e, conseqüentemente, sua disputa no mercado de trabalho.

Ou seja, o papel feminino assume outros atributos que não só ser mãe ou responsável pelos afazeres domésticos.

Esta postura foi identificada em todas as adolescentes, independente do seu segmento social. Este fato reforça que o papel da mulher, no interior da sociedade como um todo, parece estar adquirindo novos valores e, conseqüentemente, novos comportamentos diante dos mesmos. Também é preciso levar em conta que à medida em que a mulher passa a ser pressionada a entrar no mercado de trabalho, pois cada vez mais dividem as despesas familiares com os maridos ou assumem ser arrimos de família, esta própria conjuntura dá um novo perfil a própria condição feminina.

\section{O mito da homossexualidade}

As experiências homossexuais talvez sejam uma das primeiras formas de expressão do contato íntimo na adolescência. Foi considerada, como colocam CUSMINSKY \& VOJKOVIC (1992), notadamente no passado, como uma anomalia ou um desvio de comportamento, onde o tratamento era direcionado a corrigir o problema, às vezes com medidas extremas, como a utilização de choques elétricos e terapia de adversão. Hoje, apesar deste estigma já ter sido superado, carrega, ainda, grandes preconceitos em todos os segmentos da sociedade. A despeito do reconhecimento de sua existência ao longo de toda a história da humanidade, nas sociedades ocidentais as condutas homossexuais são fortemente reprimidas uma vez que, como afirma PARKER (1991), o homossexual fere a noção culturalmente definida de gênero biológico descaracterizando, conseqüentemente, os papéis sociais instituídos como inerentes a cada sexo. Com isso, destrói a noção de "macho”, vinculada a uma série de valores nos quais o simbolismo da sexualidade, poder e submissão estão claramente ligados na configuração cultural de masculinidade e feminilidade.

Dentre os adolescentes entrevistados, a homossexualidade é vista sob esta mesma ótica, ou seja, a homossexualidade masculina pode ser aceita desde que ela seja assumida discretamente. Demonstrar trejeitos femininos ou comportarse de maneira “escandalosa” é rejeitado como uma conduta aceitável ou normal, por descaracterizar a relação corpo masculino-papel masculino.

Com isso, parece que no imaginário do grupo adolescente pesquisado espera-se que a homossexualidade mantenha um caráter privado, não público, como forma de respeitar o poder atribuído ao homem, simbolicamente representado e sancionado como o sexo forte.

Nessa representação, o pressuposto presente é o de que ao imitar a mulher o homossexual despersonaliza-se do seu papel de macho, mas não consegue fazer-se idêntico à mulher ocupando, desta forma, um espaço ambíguo que o faz não pertencer a nenhuma categoria "natural”, macho e fêmea. Daí a não aceitação do homossexual que se traveste de mulher apresentar-se como simbologia de tal condição.

"A minha opinião sobre o homossexualismo é que eu não tenho preconceito contra, pessoas homossexuais normais certo, já inventei um termo, homossexuais normais... norrnais?

(O que você chama de homossexuais

O cara que é ... mas que não é aquele homossexual, aquele escandaloso, se o cara fosse homem eu não ia gostar, porque é uma coisa mais 
do comportamento e tal, mas também se quiser, eu não sou homossexual e eu acho que quem quer ser tem todo o direito assim, eu não tenho preconceito de ... só acho que o cara não precisa ficar se declarando, desmunhecando geral, é aquele que é mais é discreto, só na dele, não dá nem pra gente desconfiar, passa por homem e tudo bem" (Ademar/19 anos).

Numa situação análoga, a homossexualidade feminina também não é aceita, pois, simbolicamente, fere igualmente a condição de feminilidade, quer por alterar os comportamentos esperados para o sexo feminino, quer por deixar de assumir o desempenho do papel passivo na relação afetiva. Passa, portanto, a se constituir em uma relação de dominação. VASCONCELOS (1985) ressalta que a identidade sexual é comumente vista a partir da escolha do objeto sexual homem para a mulher e mulher para o homem, como que se ela fosse dada pelo outro e, no caso da mulher, através do resquício do mito de Adão e Eva, na qual a mulher é feita a partir daquele reforçando, assim, ainda mais a idéia de que a identidade sexual da mulher só constitui-se como dependente do sexo oposto.

"Eu gosto de homem, mas se eu gostasse de mulher eu acho que passaria por um preconceito muito grande, eu acho ridiculo, aquela mulher com jeitão de homem, falando grosso, é estranho... uma vez uma mulher se interessou por mim foi horrivel.

(Por que?)

Ah não tem nada a ver, é estranho pensar numa mulher fazendo carinhos na gente, a gente fica sempre esperando que o homem é que faça, parece que não combina” (Beatriz/ 16 anos).

É interessante observar que mesmo nas relações homossexuais questões da diferenciação de gênero estão igualmente presentes. A homossexualidade masculina é aceita, desde que ela não transfigure a relação de poder e o homem preserve sua identidade masculina. Isto pela concepção de que ele é capaz de manter o desempenho do seu papel ativo nas relações sexuais, sustentando assim o seu status de macho perante a sociedade. Já com a homossexualidade feminina o mesmo não acontece. A idéia presente é a de que ela inverte totalmente os padrões de conduta esperados no desempenho do papel feminino, pois, dada mulher, ao se tornar ativa, assume um papel que não é próprio de sua identidade. Mesmo sendo passiva na relação, dada a natureza da mesma, passa a ter um comportamento considerado como desvio da sua função biológica, qual seja, a de ser mãe e/ou esposa. Daí, observarmos, aparentemente, uma maior tolerância em relação aos comportamentos homossexuais masculinos, que em relação aos femininos.
"Eu não tenho nada contra, acho que cada um deve ter suas preferências sexuais, agora eu não me sentiria bem se uma mulher viesse pra cima de mim. mulher?)

(Você nunca se sentiu atraída por outra

Não, nunca mesmo, pros outros eu não tenho nada contra, agora comigo não ... quando a gente vê um casal de homossexuais do sexo masculino, a gente parece que aceita mais, eu pelo menos sinto assim, pra mim é estranho ver duas mulheres se tocando, se beijando, hum!!! (entonação de nojo). Não que eu não aceite nem vá criticar, eu acho que eu não sei explicar, homens tudo bem eu aceito mas mulher...

(Por que?)

Porque quando a mulher vira sapatão ela fica com aquele jeitão de homem, perde aquele jeitinho feminino da mulher, parece que quer mandar em todo mundo" (Andréa/ 19 anos).

O discurso preferido pelos adolescentes entrevistados, independente do sexo ou segmento social, foi no sentido de dar ênfase na afirmação de que eles próprios nunca tiveram qualquer tipo de prática homossexual, embora a reconhecessem como comum entre os adolescentes. Esta ênfase em demonstrar a ausência de desejo em experimentar tal prática, além de poder significar o fato de já terem feito a opção pela heterossexualidade poderia, igualmente, apontar para a necessidade de afirmação no processo de construção da masculinidade e da feminilidade do adolescente.

Neste sentido, observamos igualmente que a aceitação da homossexualidade foi colocada por alguns adolescentes como uma opção considerada "normal", desde que referida ao outro. Com isso, a despeito da preocupação em não demonstrarem preconceito contra aqueles que optaram pela homossexualidade, a convivência possível apresenta limites definidores, ou seja: seria normal desde que sua heterossexualidade fosse reconhecida e respeitada.

"Tudo bem eu respeito, não sou de criticar de achar ruim, se tem um homossexual aqui, acho que ele é gente como eu, humano como eu, não tenho nenhum preconceito, acho normal, só que eu não curto, eu não sou e também não quero que chegue perto de mim e me ofereça uma coisa dessas, eles sabem que não é o meu barato, então eles vão ficando no canto deles e eu na minha, fica melhor assim e pronto, nada de confundir" (Branca/15 anos).

Parece, no entanto, que a aceitação da homossexualidade pélo adolescente heterossexual não deixa de ocultar preconceitos a despeito de, em termos do discurso, buscar estigmatizá-la. Isto 
quando se observa que ao definir esta prática sexual, o uso de termos pejorativos é recorrentes, simbolizando, com isso, a existência de discriminação em função dos valores sociais que carrega com relação ao assunto.

"Eu respeito, acho que cada um tem um jeito de ser, de viver com quem quer, de amar quem quiser, eu não quero isso prá mim, mas tenho amigos homossexuais, eu respeito, eu acho que são pessoas maravilhosas, mas eu não consigo entender porque isso acontece na personalidade da pessoa, muito mais do que do corpo, o corpo é só uma conseqüência, acho que é por causa da criação dos pais, algum trauma de infância eu não sei, não tenho nada contra entendeu, não sou contra nem a favor, nem contra, eu aceito. Não vou dizer que eu nunca vou deixar de ser amiga porque eu tenho várias amigas que estudaram comigo que se tornaram homossexuais, adoro elas, tenho o maior carinho, mas eu não consigo dar uma explicação.

(Alguém já te cantou?)

Já, não essas amigas, sapatões que eu encontrei em discotecas, eu acho meio chato, né? Mas normal, natural” (Bianca/ 17 anos).

Muitos adolescentes, no entanto, não tiveram o menor constrangimento de se posicionarem totalmente contrários à prática de relações homossexuais, rejeitando, inclusive ter relações de amizade com pessoas homossexuais.

"A sexualidade pra mim é, existe só dois tipos: masculino e feminino, agora tem pessoas que aí já vai pro outro lado, escolhe outra opção (risos).

(Você está falando do homossexualismo?) É.

(E o que você pensa a respeito?)

Ah! ... sei lá, como eu posso dizer, eu não sou contra nem a favor, se o cara quer, problema dele só que não vem pro meu lado, não quero nenhuma aproximação, sai fora meu!'”(Bernardo/ 16 anos).

A despeito de, na sociedade moderna, observarmos um aumento da tendência a desmistificar o homossexualismo como "doença” ou "desvio” de comportamento, sua representação persiste ainda no imaginário social. Aparece como prática essencialmente patológica por contrariar não somente a lei natural das coisas expressa pela função biológica e social dos corpos, mas igualmente os desígnios superiores da criação divina.

Por fim, cabe ressaltar que as posições sobre a homossexualidade foram as mais homogêneas entre os adolescentes, indicando que os valores sociais existentes sobre tal prática encontram forte congruência tanto no interior dos segmentos sociais, quanto entre os sexos e são reveladores da grande discriminação e repulsa a este tipo de opção sexual.

Vale considerar, no entanto, que a homossexualidade vem se tornando uma prática cada vez mais comum no interior das sociedades modernas e, a despeito das resistências existentes, em alguns países, já se começar a aceitar a formalização do casamento, com todas as implicações legais advindas dele, movimento que igualmente se ensaia no Brasil.

\section{O mito da masturbação}

A masturbação talvez seja uma das práticas sexuais com maior transformação em termos de sua significação social e moral. SUPLICY (1983) coloca que no começo do século XX, o ato de masturbar-se era considerado perigosíssimo, devido a conseqüências bastante sérias tais como cegueira, surdez, debilidade mental, loucura e outros desvarios.

Mais tarde, a ela foi atribuida a responsabilidade por espinhas, impotência e até mesmo esterilidade. O hábito de masturbar-se constantemente poderia intervir nas relações sexuais, dificultando o orgasmo para a mulher e causar fraqueza ou impotência precoce, para o homem. Este caráter patológico, enfocado do ponto de vista biológico individual, deixa de existir com o avanço do conhecimento científico, mas dá lugar a uma nova forma de repressão, agora social, por reprimir o ato masturbatório através da criação de sentimentos ligados a vergonha e culpa, identificando-o com uma coisa feia e pecaminosa e que, portanto, deveria ser proibida para as crianças e abandonada pelos adultos na medida em que se tornassem mais maduros.

Foi curioso observarmos, dentre os depoimentos dos adolescentes pesquisados, discursos representando riscos ao abuso de tal prática ou ainda, possibilidades de emergência de problemas de natureza biológica. O que parece significar resquícios dessas antigas crenças ainda presentes no imaginário do jovem contemporâneo.

"Ah! Tem uma idade que é excessiva, né, não sai do banheiro, ai chega as espinhas, porque essas espinhas aqui tão meio estranhas aqui, aí chega outro e fala: sua mão tá cheia de pêlo, assim né, sua mão tá cheia de pêlo, seu pau tá em carne viva né, bem assim, você não sai do banheiro, este monte de revista, o que é isso (risada), tem essa metade também né, então é importante” (Bento/15 anos).

No entanto, o fato é que, atualmente, a masturbação tende a ser vista como fazendo parte do processo de modernização dos comportamentos sociais, como uma das formas de expressão sexual do ser humano, constituindo-se numa 
conduta saudável no processo de desenvolvimento sexual da criança e do adolescente. É concebida como um exercício para o conhecimento do próprio corpo, sofrendo profundas mudanças em termos de significação psicossocial, em decorrência das quais a noção de doença ou pecado se desloca para constituir-se num processo de auto-conhecimento do corpo. Transcende ainda, a esta autopercepção corporal, pois, não passa a ser uma prática aceita somente no período da infância ou da adolescência, mas também como forma de busca do prazer independente da idade, o que também desmistifica o caráter naturalizado a ela atribuído de "normal ou anormal”.

RODRIGUES Jr. (1993) assevera que a manipulação dos genitais com o objetivo de se obter prazer, apesar de todos os mitos que a cercam, era permitida para o sexo masculino e, muitas vezes, foi uma prática exercida em grupo, como forma de competição para se verificar quem ejaculava mais rápido. Para as meninas, no entanto, sempre houve uma enorme repressão a qualquer ato que pudesse ser associado a masturbação. A partir dos movimentos feministas, a mulher passa a reivindicar também o direito de conhecer o seu próprio corpo, dos seus potenciais e a forma de expressão da sua sexualidade.

A expressão de tal mudança ficou evidenciada na maioria dos depoimentos dos adolescentes entrevistados no interior dos quais a masturbação é identificada como fazendo parte tanto do processo de auto-conhecimento, quanto da busca pelo prazer, independente do sexo ou segmento social. Os adolescentes verbalizaram, sem nenhum constrangimento, que a masturbação faz ou já fez parte do seu cotidiano, possibilitando a descoberta e conhecimento do seu corpo. E representada como um estágio preparatório para o início da atividade sexual. Este aprendizado apresenta importante significação, pois demonstra que o adolescente percebe a cobrança excessiva que atualmente é feita para que haja um bom desempenho sexual nas relações afetivas e, para tanto, a masturbação assume um papel fundamental neste processo de socialização para a sexualidade não só na adolescência, mas também na futura vida adulta.

LEITENBERG et al. (1993), no entanto, colocam que não existe evidências empíricas da mudança do comportamento masturbatório, durante a adolescência, sobretudo no caso da mulher, pois, em seu estudo com uma amostra de 280 adolescentes voluntários da Universidade do Estado de New England, em 1988, observaram que $81 \%$ dos adolescentes masculinos e $45 \%$ dos femininos relataram masturbar-se sendo que a freqüêneia foi três vezes maior para o sexo mas- culino. Tais dados demonstram, segundo os autores, que a masturbação trata-se ainda de uma prática exercida mais pelo sexo masculino, apesar de nas gerações femininas mais recentes este percentual ter aumentado em relação a gerações anteriores. Concluem que, a despeito das mudanças sociais ocorridas que encorajam a mulher a ter uma maior percepção da sua própria sexualidade, a masturbação não tem alterado este processo de socialização.

O ponto chave da questão parece referir-se ao fato de que, apesar dos valores sociais sobre a masturbação terem mudado radicalmente, deixando de ter a conotação de pecado ou doença, ela ainda é mais facilmente incorporada pelos homens, uma vez que para a mulher tal prática implica romper limitações bastante arraigadas de bloqueios relacionados ao toque em seu próprio corpo, por carregar sentimento de vergonha ou culpa, pelo reconhecimento de seu gosto pelo prazer.

"Não acho normal [a masturbação como as pessoas pensam, ah! eu vou me masturbar, ficar tocando no meu corpo, pra ficar sentindo prazer sozinha, eu não acho legal” (Amélia/ 17 anos).

Outro fato a ser apontado é a crença ainda presente, no imaginário feminino, de que a satisfação afetiva e sexual da mulher só se realiza a partir do relacionamento com o sexo masculino e, conseqüentemente, o prazer da mulher só ocorre a partir dos carinhos e do próprio papel ativo da penetração no ato sexual. Simbolicamente faz parte do papel masculino proporcionar o prazer à mulher tendo, portanto, a obrigação de realizá-la e para tal, cabe a ele tocar e acariciar o corpo feminino.

A masturbação também é vista como forma de satisfação sexual substituta do ato sexual propriamente dito. O desejo de ficar com alguém e as fantasias sexuais aumentam e, como coloca LOYOLA \& CAVALCANTE (1989), a masturbação atende às necessidades de alívio e de tensão sexual, sem o compromisso do desempenho. Para o adolescente, no entanto, ela pode representar dois mecanismos distintos de relacionamento afetivo posterior, ou seja, vai oferecer uma condição segura para a experimentação sexual, pois propicia um domínio da auto-percepção corporal ou pode ocultar uma insegurança de se relacionar com o outro, em razão de bloqueios em assumir concretamente um relacionamento afetivo pelo temor de se aproximar ou declarar sua intenção, pelo próprio medo de fazer carícias no outro e não ser desejado ou ser rejeitado.

Segundo SUPLICY (1993), a "naturalidade" do ato de masturbar-se é vista iminentemente como uma forma de expressão da sexualidade, centrada na adolescência. Ela pode representar a 
busca da descoberta do prazer e auto-conhecimento do corpo, desde que realizada nesta fase da vida. Associa-se a masturbação na fase adulta o processo de individuação nas relações afetivas, isto é, a insegurança de se aproximar do outro na adolescência se prolongaria a ponto de dificultar que o indivíduo adulto possa ter relacionamentos maduros e saudáveis. Nessa perspectiva, não é identificada como uma maneira a mais de se relacionar consigo mesmo ou com o parceiro, pois é vista como um mecanismo de prazer solitário, não fazendo parte do relacionamento afetivo a dois.

A erofização dos meios de comunicação vem contribuindo de maneira acentuada para a modificação do comportamento sexual das pessoas, independente da idade ou classe social. Para SIMONETTI (1993), as opiniões divergem sobre o culto a erotização promovida principalmente pela televisão. Isto porque, para a autora, tanto há a possibilidade das crianças passarem a conviver com uma sexualidade menos reprimida, menos sublimada e até aprender lições capazes de melhorar a qualidade das relações pessoais, como o fato da erotização “doentia”, que invade os lares mesmo nos horários acessíveis a esta população, estar incitando uma sexualidade precoce ou "transgressora".

A questão básica é que, independente da linha de pensamento que se compartilhe, é inegável que os conteúdos dos programas televisivos ou reportagens de jornais e revistas voltados para a questão sexual produzem um estimulo ao comportamento do jovem em relação a sua sexualidade, pois o efeito visual dos meios de comunicação propicia o contato com o próprio corpo, a identificação do prazer e, conseqüentemente, as primeiras manifestações sexuais, dentre as quais o processo de masturbação que está intrinsecamente ligado. Esse fenômeno pôde ser observado nos três segmentos sociais estudados o que reforça a idéia de que a midia tem um papel prepoderante na homogeinização do comportamento adolescente.

Se por um lado, pudemos observar que a homossexualidade ainda se reveste de preconceitos pelas dificuldades da sociedade em lidar com as questões que envolvem tal prática, a masturbação parece ter sofrido uma mudança substantiva em sua conceituação sendo, para população adolescente entrevistada, mais permissiva e aceita no processo de desenvolvimento vivido na adolescência.

Para o grupo analisado, estas questões imbricam-se, em nivel do discurso preferido de tal forma que é quase imperceptível a identificação de qualquer diferenciação entre os valores sociais relacionados a essas duas práticas, havendo uma enorme proximidade de pensarnento nas categorias analisadas - segmento social e sexo.

\section{CONSIDERAÇÕES FINAIS}

A adolescência, para o conjunto de es tudantes entrevistados, independentemente do segmento social e sexo, apresenta-se como um "sentimento" vivido por todos, representado por um conjunto de identificações, Indicadoras da existência de uma identidade própria por conter, em seu conteúdo, especificidades marcadamente caracteristicas e diferenciadoras do momento de vida adolescente, daquelas relativas à infância e à idade adulta.

Como característica básica a adolescência foi representada como uma fase onde há uma frenética busca pelos prazeres da vida, na qual a diversão é significada por todos como importante elemento de identificação da identidade adolescente; representada, assim, como um momento único da vida em que todos precisan viver intensamente todas as experiências que esta fase possa proporcionar.

A assunção de poucas ou nenhuma res ponsabilidade foi identificada também como uma das características típicas da adolescên eia. Mesmo para os jovens que jà trabalham as atividades ocupacionais não são assumidas com empenho, por não serem tomadas como próprias dessa fase. São, assim, consideradas uma das formas de propiciar, a despeito de diferentes significações para os diferentes segmentos sociais, acesso à diversão, ao consumo de produtos identificadores da mesma, como a moda, bem como, notadamente no segmento social $\mathrm{A}$, à busca de certa autonomia em relação aos pais.

O estudo foi representado como a principal atribuição da adolescência, independentemente de sexo e de segmento social. Talvez por se tratar de um grupo de adolescentes estudantes tal fato assume significado relevante e estreitamento ligado ao projeto de vida do adolescente, por conter a identificação de que é através dele que se pode manter o status social existente, no caso do segmento social A, ou a possibilidade de ascensão social para os demais segmentos sociais. Para a mulher, apresenta significação peculiar pela identificação da profissionalização como elemento fundamental da construção da nova identidade feminina, o que passa a re-significar seu exclusivo papel tradicional de mãe e de esposa, redimensionando as relações de gênero na sociedade moderna.

A gravidez na adolescência foi representada como incompatível com a identidade adoles- 
cente significando elemento momentâneo de interrupção desta identidade. Vale considerar, no entanto, a especificidade do grupo investigado, uma vez que, por serem estudantes, a perspectiva da existência de um projeto de vida, onde a profissão seja valorizada, adquire sentido social.

A importância da sexualidade na formação da identidade adolescente foi representada, em nivel do discurso, por diferentes ordens de manifestações, uma vez que através dela ampliam-se as possibilidades de novas significações e identificações, permitindo que o adolescente se reconheça como tal.

Assim é que o corpo foi representado como importante elo de ligação entre os adolescentes, sendo que o padrão de beleza imposto pela mídia através do biotipo padrão da mulher - magra, alta e esguia e do homem - forte, com massa muscular, influencia na auto-estima do adolescente, assim como a forma de se relacionar com amigos/ amigas, namorados/namoradas, "paqueras”, tanto no interior do grupo de pares, quanto nas relações de gênero.

Na configuração das relações de gênero emergentes na adolescência, a identificação dos papéis feminino e masculino apresentou-se marcadamente determinada pelas relações sociais inerentes ao sistema patriarcal, ainda vigentes na moderna sociedade paulistana. São especialmente perceptíveis nas diferentes concepções presentes em relação ao "ficar” e ao namorar, para cada sexo, onde a preocupação com o controle da sexualidade feminina ainda manifesta-se nos moldes tradicionais das relações de gênero.

A menarca e a ejacularca tem representações apostas como demarcadores sociais da percepção da entrada na adolescência. Enquanto a menarca é identificada como um rito de passagem da menina para a mulher adolescente, portanto, como uma mudança de status e daí para o controle da sexualidade feminina pelas possibilidades de reprodução, o mesmo não ocorre com a ejacularca. No entanto, a possibilidade de ejaculação daí decorrente adquire forte significação como identificadora do poder de virilidade masculina, assim como da tradicional colocação de seu "poder" frente a mulher.

Dentre os adolescentes pesquisados, a virgindade não se apresenta mais como condição necessária para o casamento e, no entanto, ainda valorizada pela família da adolescente e, de maneira velada, por adolescentes masculinos do segmento social C. Porém, o número de parceiros que possam existir após o iniício da atividade sexual foi ainda representado de forma diferenciada para ambos os sexos, sendo aceito com naturalidade, estimulado e valorizado para o sexo masculino, enquanto que para o sexo feminino é, ainda, cercado de preconceito.

Os jovens estão realizando cada vez mais precocemente sua iniciação sexual com parceiros de idades similares, o que parece indicar a transformação do antigo padrão vigente na sociedade brasileira do adolescente masculino ser iniciado por mulheres mais velhas ou prostitutas e as mulheres, com seus maridos ou companheiros.

A primeira relação sexual foi representada de forma diferenciada para os adolescentes sendo, para a mulher, identificada como um acontecimento especial, idealmente esperado como decorrência da existência de um vínculo afetivo. Para o jovem, sua identificação, à semelhança da menarca para a menina, parece consistir num verdadeiro rito de passagem por representar a obtenção do atestado de virilidade masculina e sua busca de afirmação no interior das relações de gênero.

Duas categorias de medo poderiam ser destacadas como estruturantes das primeiras relações sexuais:

- para a adolescente, o medo da dor parece ocultar o medo de ser abandonada pelo parceiro após o intercurso sexual;

- para o adolescente, o medo de falhar é identificado com o temor de ser associado a ausência de virilidade.

A maioria dos jovens entrevistados tiveram a sua primeira relação sexual na sua própria casa, na casa do parceiro(a), de parentes próximos ou de amigos, demonstrando que a eterna vigilância da família em relação aos passeios externos dos adolescentes não influencia a decisão e o momento de ter, ou não, relações sexuais.

Os jovens, na sua maioria, demonstraram conhecer basicamente dois métodos contraceptivos, a pílula e o condom, não implicando tal conhecimento no uso dos mesmos como preventivo da gravidez ou de doenças sexualmente transmissíveis.

Não somente a dificuldade de prever ou planejar a primeira relação sexual, mas sobretudo a ansiedade característica da mesma, é apontada pelos jovens como dificultador na utilização de métodos contraceptivos, sobretudo a camisinha. A ocorrência das demais relações, por serem esporádicas, normalmente em local improvisado e na casa de familiares ou amigos, não são igualmente passíveis de serem previstas, e, à semelhança da primeira relação, freqüentemente rápidas, acabam por dificultar a utilização de métodos contraceptivos.

A relutância da família na aceitação da iniciação sexual feminina precoce ser desvinculada do casamento, e mesmo a "recusa" em reconhecer sua presença marcante na sociedade moder- 
na, dificulta a prevenção da gravidez na adolescência pela ausência de busca de orientação médica especializada para a utilização de métodos contraceptivos adequados.

A disseminação da AIDS e sua divulgação nos meios de comunicação têm favorecido o conhecimento sobre a importância do uso do condom passando, tal prática, a ser uma preocupação do adolescente, como forma de evitar o contágio da doença. No entanto, o discurso adolescente não reconhece sua relevância como prevenção de outras doenças sexualmente transmissíveis e mesmo da própria gravidez.

O significado social atribuído a gravidez na adolescência está relacionado não ao fato em si, mas sobretudo ao rompimento do padrão tradicional de família e presença de filhos ilegítimos que possam surgir das relações pré-maritais.

Frente a ocorrência de uma gravidez indesejada, a realização do aborto foi a primeira solução mencionada. Porém, a decisão em realizálo pareceu depender do tipo de relação afetiva existente entre o casal apresentando, inclusive, significações diferentes para os vários segmentos sociais.

Apesar do homossexualismo ser considerado, pela maioria dos adolescentes entrevistados, como prática usual na adolescência, experiências sexuais desta natureza foram negadas por todos e a opção pela homossexualidade, em contraposição a heterossexualidade, foi discriminada no âmbito dos discursos, em diferentes graus e significações.

A masturbação foi representada como uma prática normal, desde que seja praticada na adolescência, sendo caracterizada como uma busca pelo prazer individual e auto conhecimento corporal, além de manifestação positiva da sexualidade.

Diante da riqueza de significações presentes no discurso dos adolescentes, de ambos os sexos e de diferentes segmentos sociais, pudemos observar que refletir sobre temas ligados ao universo da adolescência como a construção da identidade, a configuração das relações emergentes de gênero e relações com a manifestação da sexualidade significou, no presente trabalho, penetrar no imaginário de sujeitos sociais onde valores tradicionais e modemos convivem de maneira aparentemente ambígua, configurando novas relações sociais reveladoras do amplo processo de mudança que caracteriza o ser adolescente hoje, em sua especificidade.

É neste sentido que longe de fechar questões acerca do tema, consideramos que o presente trabalho permite demonstrar a fertilidade com que se depara o investigador que pretenda mergulhar nesse rico universo de significações.

\begin{abstract}
With the aim of interpreting the conception of adolescence based on the discourse of the social subjects themselves, this study had the objective of characterizing the process of contruction ofthe adolescent's identity, starting from the mulpiple identifications that configurate it. Considering that in adolescence the emerging gender relationships and manifestations of sexuality assume par^licular significance throughout the process of identity formation, the authors also tried to focus on such aspects with the purpose of aprehending the caracteristics assumed in the process, in view of the social space in which they move. In that sense, the identification of cultural patterns and ideological an^ $\wedge$ a social values that constitute the process represent the universe of the studied group. The group was comprised of 31 student adolescents, bctwccn 15 and 19 ycars old, from both sexes, categorized in three social segments, living in a given arca of thc city of São Paulo.
\end{abstract}

Key-words: adolescent, identity, sexuality, gender, qualitative research, discourse analysis.

\section{REFERÊNCIAS BIBLIOGRÁFICAS}

ABRAMO, H. W. Cenas juvenis, punks e darks no espetáculo urbano. São Paulo, Scritta, 1994.

BARBIERE, T. Sobre a categoria gênero: uma introdução teórico-metodológica. Recife, SOS Corpo Gênero e Cidadania, 1993.

BARDIN, L. Análise de contéudo. São Paulo, Edições 70 - Persona, 1977.

BERELSON, B. Content analysis in communication research. N. York, University Press, 1971.
CIAMPA, A. C. A história do severino e a história da severina: um ensaio da psicologia social. São Paulo, Ed. Brasiliense, 1987.

CIAMPA, A. C. Identidade. In: LANE, S. T. M. \& CODO, W. (org.) Psicologia social: o homem em movimento. São Paulo, Ed. Brasiliense, 1984.

COSTA, M. R. A elaboração da identidade social In: Encontro Interdisciplinar sobre Identidade. Anais. Pontificia Universidade Católica, São Paulo, p. 49, 1983. 
CUSMINSKY, M. \& VOJKOVIC, M. C., Crescimiento y desarrollo. In: Organizacion $\mathrm{Pa}$ namericana de la Salud. Manual de medicina de la adolescência, Washington, D.C., 1992. (Serie PALTEX para Ejecutores de Programas de Salud, 20).

DESSER, A. D. Adolescencia, sexualidade \& culpa. Rio de Janeiro, Ed. Rosa dos Tempos, 1993.

DA MATA, R. A casa e a rua. São Paulo, Ed. Brasiliense, 1986.

FOUCAULT, M. História da Sexualidade. V.2, Rio de Janeiro, Ed. Graal, 1994.

FRANCO, M. L. P. B. O que é análise de conteúdo. Pontincia Universidade Católica de São Paulo/ PUC, EDUC, Programa de estudos Pós-graduados em psicologia social da educação, agosto/1986.

GASTON, J. F. et al. A closer look at adolescent sexual activity. J. Youth and Adolesc, 24(4): 465-79, 1995.

HELMAN, C. G. Cultura, saúde e doença. $2^{\mathrm{a}}$ ed., Porto Alegre, Artes Médicas, 1994.

JOSEPH, F. K. Descubrimiento e invencion de la adolescência en la história J. Adolesc. Health, 14: 664 - 72,1993.

KERGOAT, D. Relações sociais de sexo e divisão do trabalho. In: LOPES, M. J. M.; MEYER, D. E.; WALDOW, V. R., Gênero \& Saúde. p. 19-27. Porto Alegre, Artes Médicas, 1996.

LEAL, O. F. \& BOFF, A. M. Insultos, queixas, sedução e sexualidade: fragmentos de identidade masculina em perspectiva relacionar. In: PARKER, R. \& BARBOSA, R. M. (orgs.) Sexualidades brasileiras. Rio de Janeiro, Relume Durnará, p. 119-35, 1996.

LEITENBERTG, H. et al. Gender differencers in masturbation and relation of masturbation experiences in preadolescence and/or early adolescentce to sexual behavior and sexual adjustrnente in yong adulthood, Archives of Sexual Behavior, 22 (2): 589-99, 1993.

LOURO, G. L. Nas redes do conceito de gênero. In: LOPES, M. J. M. et al. Gênero e saúde. Porto Alegre, Artes Médicas, p. 7-18,1996.

LOYOLA, C. \& CAVALCANTE, M. Ampliando o conceito de sexualidade. In: CAVALCANTE, R (org). Saúde sexual e reprodutiva - ensinando a ensinar. São Paulo, Artgraf Editora, p. 315-18, 1989.

MINAYO, M. C. S. O desafio do conhecimento. Pesquisa qualitativa em saúde. $4^{\mathrm{a}}$ Ed, São Paulo/ Rio de Janeiro, Hucitec/Abrasco, 1996.
MORIN, E. Cultura de massas no séculoXX -o espírito do tempo - II necrose. $2^{\mathrm{a}}$ ed., Rio de Janeiro, Forense Universitária, 1986.

ORGANIZACION MUNDIAL DE LA SALUD. E1 embarazo e el aborto en la adolescência. In: Organizacion Mundial de la Salud, Genebra. 1975, (OMS, Série de informes técnicos, 583).

PAIVA, V. Sexualidade e gênero num trabalho com adolescentes para prevenção do HIV/ AIDS In: PARKER, R. et al (orgs.) A AIDS no Brasil. Rio de Janeiro, Relume-Dumará, ABIA, IMS, UERJ, p. 232-50, 1994.

PARKER, R. G. Corpos, prazeres e paixões - a cultura sexual no Brasil contemporâneo. São Paulo, Nova Cultural, 1991.

POPPEN, P. J. Adolescent contraceptive use and commucation: chances over a decade. Adolescence, 29 (115): 503-14, 1994.

PORTILLO, J. La sexualidad de los adolescentes. Montevideo, Editores de la Banda Oriental, 1992.

RODRIGUES Jr, O. M. Conflitos sexuais na adolescência. IN: RIBEIRO, M. (org.) Educação Sexual: novas idéias, novas conquistas. Rio de Janeiro, Ed. Rosa dos Tempos, 1993.

SAKAMOTO, C. P. M. et al. Investigação sobre saúde reprodutiva do jovem na cidade de São Paulo. São Paulo, CMVCDC, 1988.

SANCHES, R. M. Preservando-se da angústia: reflexões sobre a recusa do adolescente ao uso do preservativo. [s.l.], 1994 (mimeo).

SIMONETE, C. A influência da mídia no comportamento sexual infantil. In: RIBEIRO, $\mathrm{M}$. (org), Educação sexual: novas idéias, novas conquistas. Rio de Janeiro, Ed. Rosa dos Tempos, p. 81-88, 1993.

SUPLICY, M. Conversando sobre sexo. São Paulo, Edição da Autora, 1983.

SUPLICY, M Educação e orientação sexual. In: RIBEIRO, M. (org.), Educação sexual: nova consquistas, novas idéias. Rio de Janeiro, Ed. Rosa dos Tempos,p. 19-37,1993.

VASCONCELOS, N. Amor e sexo na adolescência. [s.1.], Moderna, 1985.

VAUGHN, I. R. et al. Adolescents and AIDS, J. Adolescent Health Care, 10: 313-316, 1989.

WHITE, S. D. \& DEBLASSE, R. R. Adolescent sexual behaviour. Adolescence, 27 (105): 18491, 1992. 